\title{
The Secretory Response of Rat Peritoneal Mast Cells on Exposure to Mineral Fibers
}

\author{
Violetta Borelli *, Elisa Trevisan, Vita Francesca and Giuliano Zabucchi \\ Department of Life Science University of Trieste, University of Trieste, 34127 Trieste, Italy; \\ elisatr@inwind.it (E.T.); vita@units.it (V.F.); zabucchi@units.it (G.Z.) \\ * Correspondence: borelliv@units.it; Tel.: +39-040-558-8660; Fax: +39-040-558-4023
}

Received: 17 November 2017; Accepted: 3 January 2018; Published: 10 January 2018

\begin{abstract}
Background: Exposure to mineral fibers is of substantial relevance to human health. A key event in exposure is the interaction with inflammatory cells and the subsequent generation of pro-inflammatory factors. Mast cells (MCs) have been shown to interact with titanium oxide $\left(\mathrm{TiO}_{2}\right)$ and asbestos fibers. In this study, we compared the response of rat peritoneal MCs challenged with the asbestos crocidolite and nanowires of $\mathrm{TiO}_{2}$ to that induced by wollastonite employed as a control fiber. Methods: Rat peritoneal MCs (RPMCs), isolated from peritoneal lavage, were incubated in the presence of mineral fibers. The quantities of secreted enzymes were evaluated together with the activity of fiber-associated enzymes. The ultrastructural morphology of fiber-interacting RPMCs was analyzed with electron microscopy. Results: Asbestos and $\mathrm{TiO}_{2}$ stimulate $\mathrm{MC}$ secretion. Secreted enzymes bind to fibers and exhibit higher activity. $\mathrm{TiO}_{2}$ and wollastonite bind and improve enzyme activity, but to a lesser degree than crocidolite. Conclusions: (1) Mineral fibers are able to stimulate the mast cell secretory process by both active (during membrane interaction) and /or passive (during membrane penetration) interaction; (2) fibers can be found to be associated with secreted enzymes - this process appears to create long-lasting pro-inflammatory environments and may represent the active contribution of MCs in maintaining the inflammatory process; (3) MCs and their enzymes should be considered as a therapeutic target in the pathogenesis of asbestos-induced lung inflammation; and (4) MCs can contribute to the inflammatory effect associated with selected engineered nanomaterials, such as $\mathrm{TiO}_{2}$ nanoparticles.
\end{abstract}

Keywords: mast cells; asbestos; crocidolite; titanium oxide nanowires; secretory process; endocytosis

\section{Introduction}

Inhaled durable particles and fibers have been of concern to human health for over a century. Many air pollutants exert their principal effect by causing oxidative stress in cells and tissues that they come in contact with. A key event in these processes is the interaction of nanoparticles with inflammatory cells and the subsequent production of pro-inflammatory factors.

Many reports have been published on the "in vitro" interaction of different types of polluting nanoparticles/fibers with inflammatory cells and on the "in vivo" outcome of the exposure of experimental animals to different types of particulate matter. Exposure to asbestos fibers and to titanium oxide $\left(\mathrm{TiO}_{2}\right)$ nanoparticles (NPs) is of significant relevance for human health.

Asbestos has been banned, but its effects (aggressive lung tumors and chronic lung inflammation/fibrosis) in exposed subjects is expected to reach its peak in 2025 [1]. Conversely, $\mathrm{TiO}_{2}$ nanoparticles (NPs) have received a much attention due to their widespread and increasing use in products such as sunscreens, cosmetics, toothpaste, pharmaceuticals, paints, plastics, self-cleaning devices, food additives, papers, solar cells, and a corrosion-protective coating in bone implants, leading to high human and environmental exposure. Generally, $\mathrm{TiO}_{2}$ is considered a low toxicity $\mathrm{NP}$, although 
if it reaches the pulmonary interstitium it can exert a certain degree of cytotoxicity [2]. However, recent studies have reported that the degree of toxicity of $\mathrm{TiO}_{2}$ can depend on physicochemical parameters, such as the morphology of $\mathrm{TiO}_{2} \mathrm{NPs}$, size, aggregation, crystal phase, and surface modifications [3-5]. They have been shown to be cytotoxic for both epithelial and inflammatory cells [3,6-8] and induce the production of reactive oxygen species (ROS) from phagocytic cells [5,6,8-10]. A cytotoxic effect of $\mathrm{TiO}_{2} \mathrm{NPs}$ for these cells (and fibroblasts) was also shown in other studies [11-14]. The pro-inflammatory power of $\mathrm{TiO}_{2} \mathrm{NPs}$ has also been tested in "in vivo" studies [15]. Very recently, it was also shown that $\mathrm{TiO}_{2} \mathrm{NPs}$ can induce an inflammatory reaction in exposed subjects who prepare $\mathrm{TiO}_{2}$ from ilmenite ore $[16,17]$. $\mathrm{TiO}_{2} \mathrm{NPs}$ can promote the expression and release of both $\mathrm{T}$ helper lymphocyte type 2 (Th2) and type 1 (Th1) cytokines [3,4,12,18-20]. Supporting the Th2-promoting activity of $\mathrm{TiO}_{2}$, it was shown that these nanoparticles can potentiate allergic reactions [21-23] and that intratracheally instilled $\mathrm{TiO}_{2} \mathrm{NPs}$ induce an increased number of mast cells (MCs) and increase interleukin 13 (IL13) secretion in the bronchoalveolar lavage (BAL) of treated rats [24]. Only in two studies have conflicting results been obtained $[25,26]$. It is noteworthy that these experimental models have examined different administration routes, doses employed, time of exposure, and types of $\mathrm{TiO}_{2} \mathrm{NPs}[20,27]$. Apart from quantitative effects, the qualitative effects of $\mathrm{TiO}_{2}$ particles of different morphology and structure are very similar in terms of pro-inflammatory (i.e., ROS production, cytokine production, ingestion path) and cytotoxic activity $[3,4,8,10,13]$, even independently of the administration route $[4,12,13,20,27]$. Interestingly, $\mathrm{TiO}_{2} \mathrm{NPs}$ and nanowires appear to be taken up by inflammatory and epithelial cells through two pathways: endocytosis and penetration, with the latter being suggested by the presence of free cytosolic $\mathrm{TiO}_{2} \mathrm{NPs}$ in the absence of a limiting endosome membrane $[4,6,11,14,28,29]$. Intriguingly, it has been suggested that asbestos fibers may also reach the cell interior by the same pathways [30-32].

Asbestos fibers have been widely recognized as strong pro-inflammatory and mutagenic compounds [33-35], although their mechanism of action is still unclear. The interaction between asbestos fibers and professional phagocytes has been widely studied in recent years [30,36-47]. When exposed to asbestos, these cells produce free radicals [34,48] and cytokines [35], ingest the fibers, undergo endoplasmic reticulum stress, and trigger the apoptotic program $[49,50]$.

In addition to proinflammatory and cytotoxic activity, and cell penetration pathways, $\mathrm{TiO}_{2} \mathrm{NPs}$ and asbestos fibers also share other features. Yazdi et al. [51] have shown that $\mathrm{TiO}_{2} \mathrm{NPs}_{\text {activate }}$ the NLR pyrin domain-containing 3 (NLRP3) inflammasome, which is involved in inflammation and other immune responses, leading to interleukin (IL)- $1 \beta$ release, and induces the regulated release of IL- $1 \alpha$. The same activity is also exerted by asbestos fibers [52]. As with $\mathrm{TiO}_{2} \mathrm{NPs}$, asbestos fibers can provoke marked pulmonary eosinophilia, suggesting activation of Th2 immune reaction [53,54], and increase the incidence of respiratory symptoms and asthma in human beings [55]. Moreover, it was shown that amphibole fibers (including crocidolite) induce the expression of Th2-and Th1 cytokines in mouse lungs $[4,11,22,23,54]$.

MCs have recently been identified among inflammatory cells with properties peculiar to professional phagocytes [56-59]. MCs are well known for their role in the initiation of allergic diseases $[60,61]$ and in pathogen recognition [61-64]. Despite the fact that MCs are present, together with professional phagocytes, in the entry site of the inhaled fibers [65-68], little is known about the mast cell-NP/fiber interaction. Seminal papers have suggested that MCs are associated with interstitial fibrosis and granuloma formation induced by asbestos fibers in rats [68-70]. Fibrosis, which is a key event in asbestos-related disease, together with the inflammatory reaction, can be promoted by MC granule content such as tryptase, a key enzyme for profibrotic activity, and chymase, which can also act as a proinflammatory and profibrotic enzyme [71]. Mast cell chymase promotes hypertrophic scar fibroblast proliferation and collagen synthesis by activating the TGF- $\beta 1 /$ Smad signaling pathway. These aspects potentially link MC secretory activity with premalignant stages in asbestos-related diseases.

Recently, it has been shown that MCs appear to contribute to the inflammatory and toxic effects associated with selected engineered nanomaterials [72] with fibrous structures similar to asbestos, 
exposure to which may lead to asbestos-like diseases in animal models [73,74]; silver nanoparticles are also capable of stimulating $\mathrm{MC}$ degranulation [75]. Finally, $\mathrm{TiO}_{2} \mathrm{NPs}$ have also been shown to stimulate a mast cell-like cell line to secrete histamine [76] and to increase the number of these cells in the trachea of treated rats [24].

Considering that MCs have been shown to be a target of $\mathrm{TiO}_{2} \mathrm{NPs}$ and asbestos fibers, we hypothesized that both can stimulate mature MC secretion.

In this paper, we compare the response of rat peritoneal mature mast cells (RPMCs) challenged with identical concentrations of the following mineral fibers: $\mathrm{TiO}_{2}$ nanowires $\left(\mathrm{TiO}_{2} \mathrm{NWs}\right)$, asbestos in the form of amphibole-type crocidolite (CRO) fibers, and wollastonite (WOLLA), a fibrous calcium silicate which is thought to have lower toxicity levels and low pro-inflammatory power compared to asbestos [77]. Our findings show that $\mathrm{CRO}$ and $\mathrm{TiO}_{2} \mathrm{NWs}$ are capable of triggering a dramatic secretory response in RPMCs, with the former inducing the highest activity.

\section{Materials and Methods}

\subsection{Reagents}

Triton X-100, bovine serum albumin (BSA), human chymase, human tryptase, $o$-phthalaldehyde, histamine, 3,3',5, $5^{\prime}$-Tetramethylbenzidine (TMB), Percoll and compound 48/80 were obtained from Sigma-Aldrich S.R.L. Milan (Italy). High-purity trypan blue (TB) (color index 23850) was obtained from Merck KGaA (Darmstadt, Germany). All other chemicals were of reagent grade.

\subsection{Mineral Fibers}

$\mathrm{TiO}_{2}$ nanowires were obtained from Sigma-Aldrich S.R.L. (product number: 774510). Wollastonite, as a non-asbestos silicate powder, was used as a control particulate and was a kind gift of Bal-Co. SpA (Sassuolo, MO, Italy). Wollastonite characterization was also reported by Governa et al. 1998 [77]. An Analytical Standard UICC sample of crocidolite was obtained from SPI-CHEM West Chester, PA, USA, re-suspended in phosphate buffered saline (PBS) at a final concentration of $10 \mathrm{mg} / \mathrm{mL}$, and stored at $4{ }^{\circ} \mathrm{C}$ until use. The fiber size parameters of the asbestos UICC standard have been described in detail by Kohyama et al. [78]. The reference batch of the standard sample was Crocidolite South African 12001-28-402704-AB. All fiber types in PBS were left to sediment for 2 min to avoid larger fiber aggregates.

\subsection{Characterization of Fibers by SEM-Energy Dispersive X-ray Spectrometry (EDX) Analysis}

The fibers, resuspended in distilled water, were directly mounted onto stubs using double-sided adhesive, sputter coated with gold in a Edwards S150A apparatus (Edwards High Vacuum, Crawley, West Sussex, UK), and examined with a Leica Stereoscan 430i scanning electron microscope (Leica Cambridge Ltd., Cambridge, UK), equipped with a SEM-EDX (Oxford Instruments, Oxford, UK), and a PENTAFET PLUS TM Si(Li) detector that allowed chemical characterization. Supplementary Figures S1-S3 show the ultrastructural morphology and chemical composition of the mineral fibers employed. The chemical compositions of crocidolite and $\mathrm{TiO}_{2} \mathrm{NWs}$ were found to be compatible with those already reported by other authors $[79,80]$. As expected, WOLLA (a calcium inosilicate) was revealed to be mainly composed of calcium and silicon. The detailed morphological analysis carried out on at least 100 fibers showed that crocidolite fibers had an average length of $9.2 \pm 1.5 \mu \mathrm{m}$ (Standard Error, SE) (range minimum-maximum 2.1-35.7); wollastonite $4.2 \pm 0.79 \mu \mathrm{m}$ (SE) (range min-max 1.7-27.6); and $\mathrm{TiO}_{2} \mathrm{NWs} 2.9 \pm 0.5 \mu \mathrm{m}$ (SE) (range min-max 1.0-20.2).

\subsection{Animals}

All experimental procedures involving the use of rats were reviewed and approved by the Trieste University Animal Care and Use Committee (Protocol \# 387Bor11 14 April 2011, as received from Italian Ministero della Salute on 26 April 2011) and were performed in accordance with the Italian 
Laws (D.L.vo 116/92 and following additions), which enforce Directive EU 86/609. All animals were housed under pathogen-free conditions with light-dark cycles, fed standard animal chow, and given free access to autoclaved distilled water from bottles.

\subsection{Rat Peritoneal Cell Preparation, Mast Cell Purification, and Cell Viability}

Wistar male or female rats (200 to $400 \mathrm{~g}$ ) purchased from the animal facility of the University of Trieste were used. Rats were killed using $\mathrm{CO}_{2}$ inhalation. As judged by optical analysis of cytospin specimens (Cytospin 2, Shandon Inc., Pittsburgh, PA, USA) stained with the Diff-Quik system (Medion Diagnostics, Gmbh, Düdingen, Switzerland), highly purified (>95-97\%) peritoneal mast cells (RPMCs) and contaminating peritoneal macrophages $(2-5 \%)$ were obtained by centrifugation on Percoll gradient, as previously described [81]. RPMC viability (Trypan blue exclusion test) was over $95 \%$ at the beginning of the experiment. RPMCs were washed once in PBS containing 0.5\% BSA, counted electronically (Coulter Counter ZBI, Luton, UK), and suspended in a buffered saline solution containing BSA (BSSA: $142 \mathrm{mM} \mathrm{NaCl}, 2.7 \mathrm{mM} \mathrm{KCl}, 0.5 \mathrm{mM} \mathrm{CaCl}_{2}, 8 \mathrm{mM} \mathrm{Na}_{2} \mathrm{HPO}_{4}, 10 \mathrm{mM} \mathrm{KH}_{2} \mathrm{PO}_{4}, 1.2 \mathrm{mM} \mathrm{MgCl}_{2}$, and $0.1 \%$ BSA) as previously described [81].

\subsection{RPMC Lysate Preparation and Treatment}

RPMCs $\left(3 \times 10^{6}\right.$ cells $/ \mathrm{mL}$ in BSSA) were sonicated for $2 \mathrm{~min}$ at maximum power in a Bandelin Sonopuls Sonifier UW2070 (Berlin, Germany) which ensures the near complete disruption of both cells and organelles, and subsequently incubated for $30 \mathrm{~min}$ at $37^{\circ} \mathrm{C}$ with mineral fibers $(100 \mu \mathrm{g} / \mathrm{mL})$. The quality of the lysate was monitored by checking that, after centrifugation $(15 \mathrm{~min}$ at $250 \times \mathrm{g}$ ) of the untreated lysate, less than $17 \%$ of the enzyme activity was found in the pellet fraction. Following incubation with fibers, enzymatic activities for chymase (CHY), tryptase (TRY) and $\beta$-hexosaminidase ( $\beta$-hexo) were measured (without detergent which could in theory interfere with fiber absorption capacity) in lysates, to evaluate a possible inhibitory or stimulatory effect induced by fibers. Subsequently, the mixture was centrifuged $15 \mathrm{~min}$ at $250 \times \mathrm{g}$ at $4{ }^{\circ} \mathrm{C}$ and the supernatant and the pellet (containing all the fibers added) were carefully collected. The enzyme activities were measured again in these fractions to assess their possible fiber-association.

\subsection{RPMC Fiber Interaction}

RPMCs $\left(3 \times 10^{6}\right.$ cells $/ \mathrm{mL}$ in BSSA) were incubated (5-30 min, as indicated, at $\left.37^{\circ} \mathrm{C}\right)$ alone, with mineral fibers $(100 \mu \mathrm{g} / \mathrm{mL})$, or stimulated to degranulate by adding compound $48 / 80$ to a final concentration of $10 \mu \mathrm{g} / \mathrm{mL}$. To stop the interaction, tubes were rapidly chilled in ice. Cytospin specimens of the incubation mixtures were stained with the Diff-Quik system to assess morphologically the degranulation process. Cells were then pelleted by centrifuging $10 \mathrm{~min}$ at $200 \times \mathrm{g}$ at $4{ }^{\circ} \mathrm{C}$, the supernatant (SN) was carefully collected, and the cell pellet $(\mathrm{P})$ was resuspended in the same volume of BSSA.

\subsection{Release of Granule Components}

The amount of released granular mediators was determined by measuring the activities of $\beta$-hexo, TRY, CHY, and the presence of histamine in supernatants (SN) and pellets (P). The enzymatic activities in the cell fractions (solubilized with $0.05 \%$ Triton $X-100$ ) were determined using the following substrates: 4-nitrophenyl $N$-acetyl- $\beta$-D-glucosaminide for $\beta$-hexo, $N$-( $p$-Tosyl)-Gly-Pro-Lys 4-nitroanilide ( $0.25 \mathrm{mM}$ final concentration) for TRY, and $N$-succinyl-Ala-Ala-Pro-Phe- $p$-nitroanilide ( $0.2 \mathrm{mM}$ final concentration) for CHY. The supernatant and pellet enzymatic activities were assayed in triplicate in 96-wells plates, and measured in an ELISA reader (Multiskan ${ }^{\mathrm{TM}}$ FC Microplate Photometer; Thermo Fisher Scientific, Waltham, MA, USA) at $405 \mathrm{~nm}$. Histamine content was assessed by a fluorometric assay in a Perkin Elmer spectrophotofluorimeter $(\lambda 5)$ using $o$-phthaldehyde $(\mathrm{OPT})$ reaction as previously described [82]. The extent of secretion was calculated by considering the total enzyme activity or histamine amount $(\mathrm{SN}+\mathrm{P})$ as $100 \%$. 


\subsection{Granule Preparation and Granule-Fiber Interaction}

Intact mast cell granules enveloped by their individual perigranular membranes were obtained by mild sonication ( $1 \mathrm{~min}$ at 50\% power in Bandelin Sonopuls Sonifier UW2070, Berlin, Germany) of the MC suspension as described by Lindstedt and Kovanen [83]. Granule remnants were obtained by weak 48/80 stimulation ( $15 \mathrm{~min}$ with $1 \mu \mathrm{g} / \mathrm{mL} 48 / 80$ ) of MC as previously described [83]. Granule structures were incubated with $100 \mu \mathrm{g} / \mathrm{mL}$ mineral fibers for $30 \mathrm{~min}$ at $37^{\circ} \mathrm{C}$, and then processed for scanning electron microscopy.

\subsection{Optical and Ultrastructural Scanning Electron Microscope Analysis (SEM)}

At the end of the incubation, cell/fibers or granule/fibers suspensions were stained with the Diff Quik System or fixed in $2 \%$ glutaraldehyde in 0.1 sodium cacodylate buffer ( $\mathrm{pH} 7.4$ ) for $30 \mathrm{~min}$. Fixed cells were washed twice in sodium cacodylate buffer $(0.1 \mathrm{M} \mathrm{pH} 7.4)$ placed on glass coverslips (previously coated with poly-L-lysine) for $1 \mathrm{~h}$, and then processed for scanning electron microscopy (SEM). The procedure to analyze the samples by SEM has been previously described elsewhere [31]. Samples rinsed in PBS were dehydrated in ascending ethanol concentrations and transferred in 100\% ethanol to a critical point dryer (Bal-Tec; EM Technology and Application, Furstentum, Liechtenstein) and dried through $\mathrm{CO}_{2}$. Coverslips were mounted on aluminum sample stubs and gold-coated by sputtering (Edwards S150A apparatus; Edwards High Vacuum, Crawley, West Sussex, UK). SEM images were obtained using a Leica Stereoscan 430i scanning electron microscope (Leica Cambridge Ltd., Cambridge, UK).

\subsection{Transmission Electron Microscope Analysis (TEM) Fibers}

RPMCs $\left(3 \times 10^{6}\right.$ cells in BSSA) were challenged with mineral fibers $(100 \mu \mathrm{g} / \mathrm{mL})$ for $30 \mathrm{~min}$ at $37^{\circ} \mathrm{C}$, and were subsequently fixed for $30 \mathrm{~min}$ at room temperature in a solution of $1.5 \%$ glutaraldehyde (Serva, Heidelberg, Germany) in $0.1 \mathrm{M}$ sodium cacodylate buffer ( $\mathrm{pH}$ 7.4) containing $0.03 \mathrm{M} \mathrm{CaCl}_{2}$. As previously described [58], samples were washed twice with sodium cacodylate buffer ( $\mathrm{pH}$ 7.4) and then post-fixed with $1 \% \mathrm{OsO}_{4}$ for $1 \mathrm{~h}$ at $4{ }^{\circ} \mathrm{C}$. Post-fixed cells were dehydrated with a graded ethanol series ending with 100\% ethanol and then embedded in Dow epoxy resin (DER332; Unione Chimica Europea, Milan, Italy) and DER732 (Serva, Heidelberg, Germany). Ultrathin sections were prepared with an Ultrathome III (Pharmacia-LKB, Uppsala, Sweden) and double stained with uranyl acetate and lead citrate. Serial sections were obtained by spanning 120-720 nm from the initial level. All the sections were analyzed using a Philips EM208 transmission electron microscope (Philips, Eindhoven, The Netherlands) equipped with a Quemesa Camera (Olympus Soft Imaging Solutions, Munster, Germany).

\subsection{Peroxidases}

Myeloperoxidase (MPO) and eosinophil peroxidase (EPO) were obtained from human blood granulocytes as described previously [84]. Purified MPO had a ratio of absorption in the Soret region $428 / 280 \mathrm{~nm}$ (ratio of Reinheitzahl (Rz)) commonly used as a criterion of purity for heme peroxidases) of 0.8 , which indicates a high level of purity; its concentration in $25 \mathrm{mM}$ phosphate buffer ( $\mathrm{pH} 7.0$ ) was $1.6 \mathrm{mg} / \mathrm{mL}(10.7 \mu \mathrm{M})$. Purified EPO (protein concentration, $0.32 \mathrm{mg} / \mathrm{mL}[5 \mu \mathrm{M}]$ in $25 \mathrm{mM}$ phosphate buffer ( $\mathrm{pH} 7.0$ ) had the typical absorbance spectrum reported previously and had an $\mathrm{Rz}$ of 1.10. The enzymatic activity of MPO and EPO was analyzed using the TMB method [85].

\subsection{Isoelectric Point (IP)}

The theoretical IPs for the enzymes considered in this paper are those reported in the UniProt universal protein knowledgebase web site (Nucleic Acids Res. 45: D158-D169 (2017)). 


\subsection{Statistical Analysis}

Statistical significance was tested by a two-tailed Student's $t$ test for paired samples using GraphPad Prism 5.0 (GraphPad Software, La Jolla, CA, USA). When assessing the statistical significance of increased enzyme activity, one sample $t$ test was used to calculate to what extent the mean values differed from a hypothetical value of 100 . Values of $p \leq 0.05$ were considered statistically significant.

\section{Results}

\subsection{Morphological Analysis of Mineral Fiber-RPMC Interaction by Light and Electron Microscopy}

Figure 1a shows the appearance of a population of unstimulated rat mast cells. They appear compact and maintain this morphology up to $30 \mathrm{~min}$ of incubation. After as little as $5 \mathrm{~min}$ of exposure, crocidolite (CRO) fibers induce RPMC degranulation. The interacting cells become enlarged and show scattered granules, which appear to be independent of one another and are projected to the cell periphery (Figure $1 \mathrm{~b}$ ). The process reaches its maximum after $30 \mathrm{~min}$ of incubation, when most of the RPMCs appear to be disrupted (Figure 1c). As shown in Figure 1b,c, secreted granules can be seen adhering to the fibers. The affinity of this binding was shown by isolating RPMC membrane-covered granules and incubating them directly with CRO. Figure $1 \mathrm{~d}$ shows isolated granules adhering to asbestos fibers. CRO seems to trigger an RPMC explosion, with expulsion of many granules/granule remnants at the same time. Most fibers displayed large numbers of bound granules. Figure 1e shows the appearance of an RPMC incubated for $30 \mathrm{~min}$ with $\mathrm{TiO}_{2} \mathrm{NWs}$ : two nanowires (Figure 1e inset) are visible inside the RPMC. Even in this case the degranulation process is evident: the cells exhibit enlarged and scattered granules, suggesting that $\mathrm{TiO}_{2} \mathrm{NWs}$ can also induce RPMC degranulation. On the contrary, incubation with WOLLA did not result in RPMC degranulation. In Figure 1f cells appear to maintain their unstimulated morphology even after the end of the incubation. Compound 48/80, a well-known inducer of MC secretion, also had a significant effect. After $5 \mathrm{~min}$, it induced the progressive degranulation of the RPMCs (Figure 1g) leading, eventually, to the formation of RPMC ghosts (Figure $1 \mathrm{~h}$ and inset). In order to gain further insight into the mechanism of mineral fibers-RPMC interaction, we carried out scanning electron microscope (SEM) and transmission electron microscope (TEM) analyses. Figure 2a shows the SEM appearance of unstimulated RPMCs, with some granule profiles protruding beneath the plasma membrane level. As expected, stimulation for 30 min with 48/80 elicited degranulation (Figure $2 \mathrm{~b}$ and inset). After 30 min incubation, CRO stimulated RPMCs to secrete their granules, which were subsequently found to be associated with the fibers themselves (Figure 2c arrowhead). In some cases (Figure $2 \mathrm{~d}$ and inset), single fibers were seen entrapped in the RPMCs. Figure 2e shows that RPMCs were also able to entrap $\mathrm{TiO}_{2} \mathrm{NWs}$ and undergo degranulation. Even in this case, the secreted granules appeared to bind to extracellular NWs (Figure 2e). Figure $2 \mathrm{f}$ (and inset) shows the appearance of an RPMC exposed to WOLLA for comparison. In this case, the cells maintained their unstimulated morphology during the entire incubation time, despite the large number of WOLLA fibers deposited on their surface. Free granules were only rarely seen.
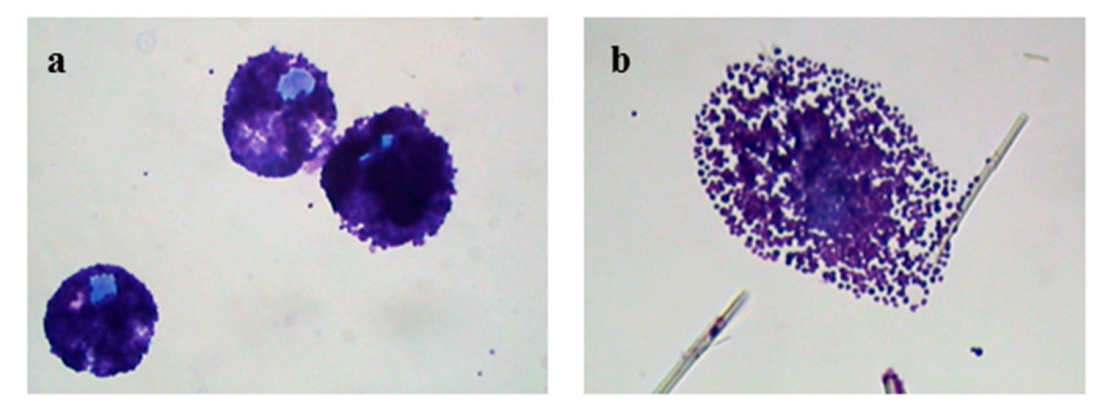

Figure 1. Cont. 

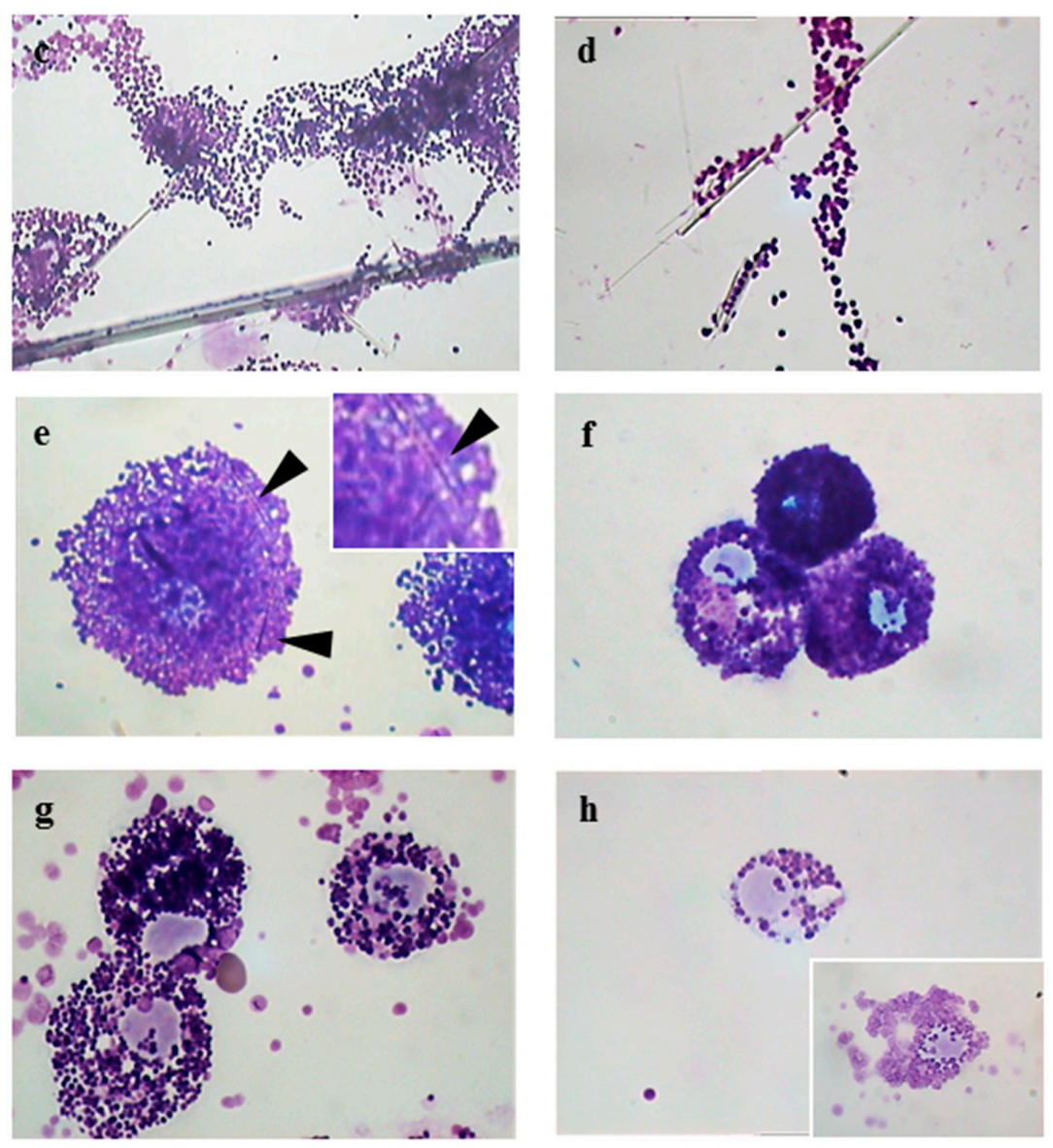

Figure 1. Light microscope appearance of rat peritoneal MCs (RPMCs) exposed to mineral fibers or stimulated with compound 48/80. (a) Unstimulated RPMCs after 30 min of incubation; (b,c) RPMCs exposed to $100 \mu \mathrm{g} / \mathrm{mL}$ of crocidolite fibers after 5 or $30 \mathrm{~min}$ of incubation; (d) isolated RPMC membrane-covered granules incubated with $100 \mu \mathrm{g} / \mathrm{mL}$ of crocidolite for $30 \mathrm{~min}$; (e) an RPMC exposed to $100 \mu \mathrm{g} / \mathrm{mL} \mathrm{TiO}_{2}$ nanowires (NWs) after $30 \mathrm{~min}$ of incubation, arrowheads show intracellular nanowires and in the magnified inset the arrowhead shows a nanowire inside the cell; (f) RPMCs exposed to $100 \mu \mathrm{g} / \mathrm{mL}$ of wollastonite fibers after $30 \mathrm{~min}$ of incubation. ((g,h), inset) RPMCs stimulated with compound $48 / 8010 \mu \mathrm{g} / \mathrm{mL}$ after 5 or $30 \mathrm{~min}$ incubation; the pictures are representative of at least ten different experiments. Cytocentrifuge-prepared samples were stained with the Diff-Quik system. Original magnification $=1000 \times$. 

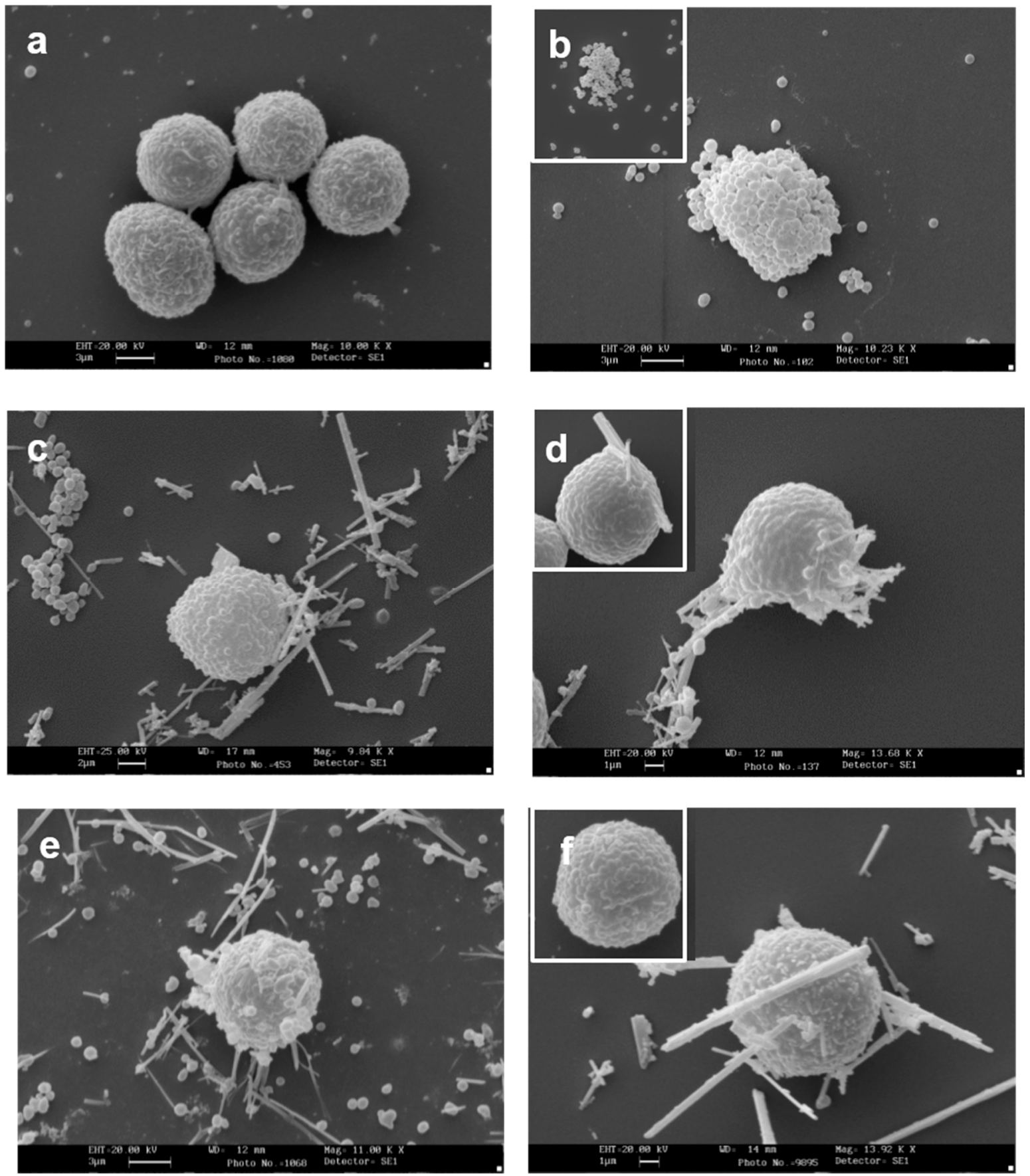

Figure 2. Scanning electron microscope appearance of RPMCs exposed to mineral fibers or stimulated with compound 48/80. (a) Unstimulated RPMCs after 30 min of incubation; (b) RPMCs exposed to $10 \mu \mathrm{g} / \mathrm{mL}$ compound 48/80 for $30 \mathrm{~min}$ : a large number of granules are secreted and the cell surface shows many protruding granules, while the inset shows an RPMC ghost induced by 48/80; (c,d) RPMC exposed to $100 \mu \mathrm{g} / \mathrm{mL}$ crocidolite for $30 \mathrm{~min}$ : an evident secretory response is shown, fiber-bound free granules as well as granule clusters can be seen, and numerous granule profiles protrude from the cell surface. ((d) and inset) Asbestos fibers can be seen, entrapped by the RPMC; the fibers may have reached the cell interior by either penetration or frustrated phagocytosis; (e) an RPMC exposed to $100 \mu \mathrm{g} / \mathrm{mL} \mathrm{TiO}_{2} \mathrm{NWs}$ for $30 \mathrm{~min}$. Note that numerous fibers interact with cell and free granules; ((f) and inset) an RPMC exposed to $100 \mu \mathrm{g} / \mathrm{mL}$ wollastonite fibers for $30 \mathrm{~min}$. Note that despite many fibers being deposited on the RPMC surface there is no sign of degranulation. Magnification: bars in $(\mathbf{a}, \mathbf{b}, \mathbf{e})=3 \mu \mathrm{m} ;$ bars in $(\mathbf{c})=2 \mu \mathrm{m} ;$ in $(\mathbf{d}, \mathbf{f})=1 \mu \mathrm{m}$. 
In all these cases the extracellular granules could derive from either an active degranulation process or from direct rupture of the RPMC followed by the passive release of membrane-covered granules. To provide more insight into this problem, we isolated membrane-covered granules and granule remnants and challenged them firstly with the more active mineral fiber, crocidolite. The results (Supplementary Figure S4 panel a) shows the appearance of membrane-covered granules compared to panel $b$, which shows granule remnants isolated following secretion induced by $48 / 80$. The granules, immediately fixed after isolation, show a very similar morphology. However, the diameter of granule remnants was slightly but highly and significantly $(p<0.005)$ increased with respect to membrane-covered granules $(0.70 \mathrm{~mm} \pm 0.02 \mathrm{SE}$ vs. $0.80 \mathrm{~mm} \pm 0.02$ mean $\pm \mathrm{SE}$, with more than 200 observations carried out on 15 different SEM fields). The major difference was adhesion to CRO fibers. Detailed counts on at least 10 different SEM fields revealed that on average 0.24 granule remnants and 2.2 membrane-covered granules were bound to one CRO fiber. Panel C and E clearly show a difference. Since more active adhesion of granule fibers was found with membrane-covered granules, we employed the latter to further study the outcome of their incubation with mineral fibers.

Figure 3 shows the interaction of $\mathrm{CRO}$ and $\mathrm{TiO}_{2} \mathrm{NWs}$ with isolated MC membrane-covered granules. This interaction, in agreement with the findings obtained by light microscope analysis, appeared to be remarkably consistent (Figure 3b). Granule-free $\mathrm{CRO}$ was rarely observed. $\mathrm{TiO}_{2} \mathrm{NWs}$ displayed lower, yet still consistent, interaction with isolated granules (Figure 3c).

Since the more potent effect was registered with CRO fibers, these were used to stimulate RPMCs for TEM analysis. The objective was to investigate whether, as already shown for $\mathrm{TiO}_{2}$ nanoparticles [5,7,31], asbestos fibers can also penetrate RPMCs. CRO interacts with the RPMC surface in different ways: some fibers are embraced by MC pseudopodia and presumably ingested (Figure $4 \mathrm{a}-\mathrm{c}$ ), while some simply adhere, and the majority seem to be included in the RPMC cytosol (arrowhead in Figure 4a,d), while only rarely can a phagosome be seen surrounding them. The appearance of TEM suggests that the secretion can be carried out through: (1) active single granule secretion (Figure $4 \mathrm{~d}$ arrow) and the conventional compound exocytosis pathway (Figure 5b), when the granule membranes fuse to each other, forming large vacuoles whose content is subsequently released extracellularly in one step; and (2) following membrane rupture and passive granule expulsion (Figure 5c). It is worth noting that the ultrastructure of asbestos-challenged RPMCs showed a weaker reaction to fiber exposure when analyzed by TEM and SEM than that observed by light microscopy. Most of the cells were intact and only rarely exhibited an explosive reaction. Almost all the RPMCs interacting with the fibers showed signs of activated secretion. It can be excluded that the nude asbestos fibers visible in the cytosol are artefacts introduced by the preparation and processing of the cell sections for TEM analysis, since serial sections of the same cell show the presence of the same fiber spanning either 120 or $720 \mathrm{~nm}$ in depth (see Supplementary Figures S5 and S6). The analysis of an eosinophil gave the same result (Supplementary Figure S7). 

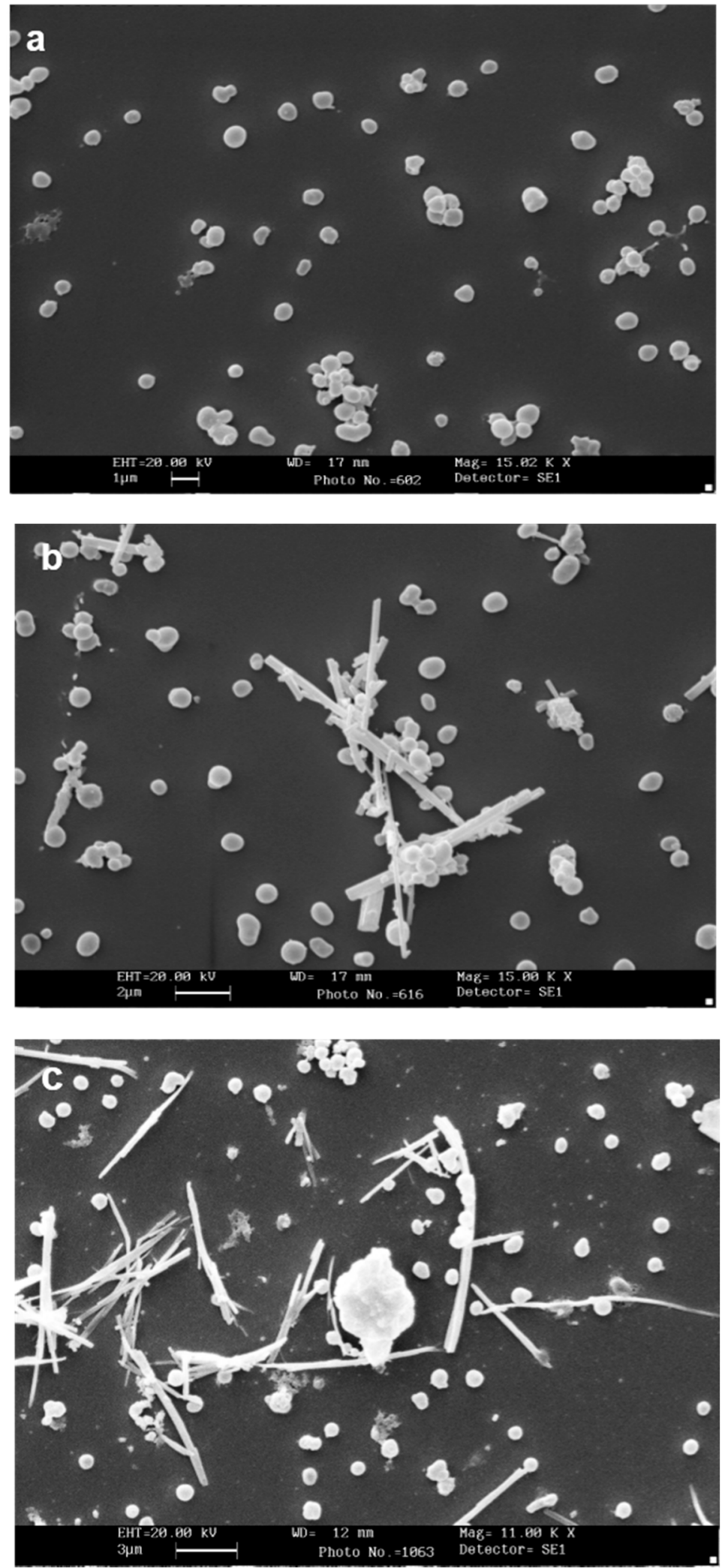

Figure 3. Interaction of RPMC-isolated granules with crocidolite as observed by SEM. (a) Isolated membrane-covered granules alone; (b) isolated membrane-covered granules incubated with $100 \mu \mathrm{g} / \mathrm{mL}$ of crocidolite fibers; (c) isolated membrane-covered granules incubated with $100 \mu \mathrm{g} / \mathrm{mL}$ of $\mathrm{TiO}_{2} \mathrm{NWs}_{\text {. }}$ A fiber-bound cluster of granules can be seen. Magnification: bars in $(\mathbf{a})=1 \mu \mathrm{m} ;(\mathbf{b})=2 \mu \mathrm{m} ;(\mathbf{c})=3 \mu \mathrm{m}$. 

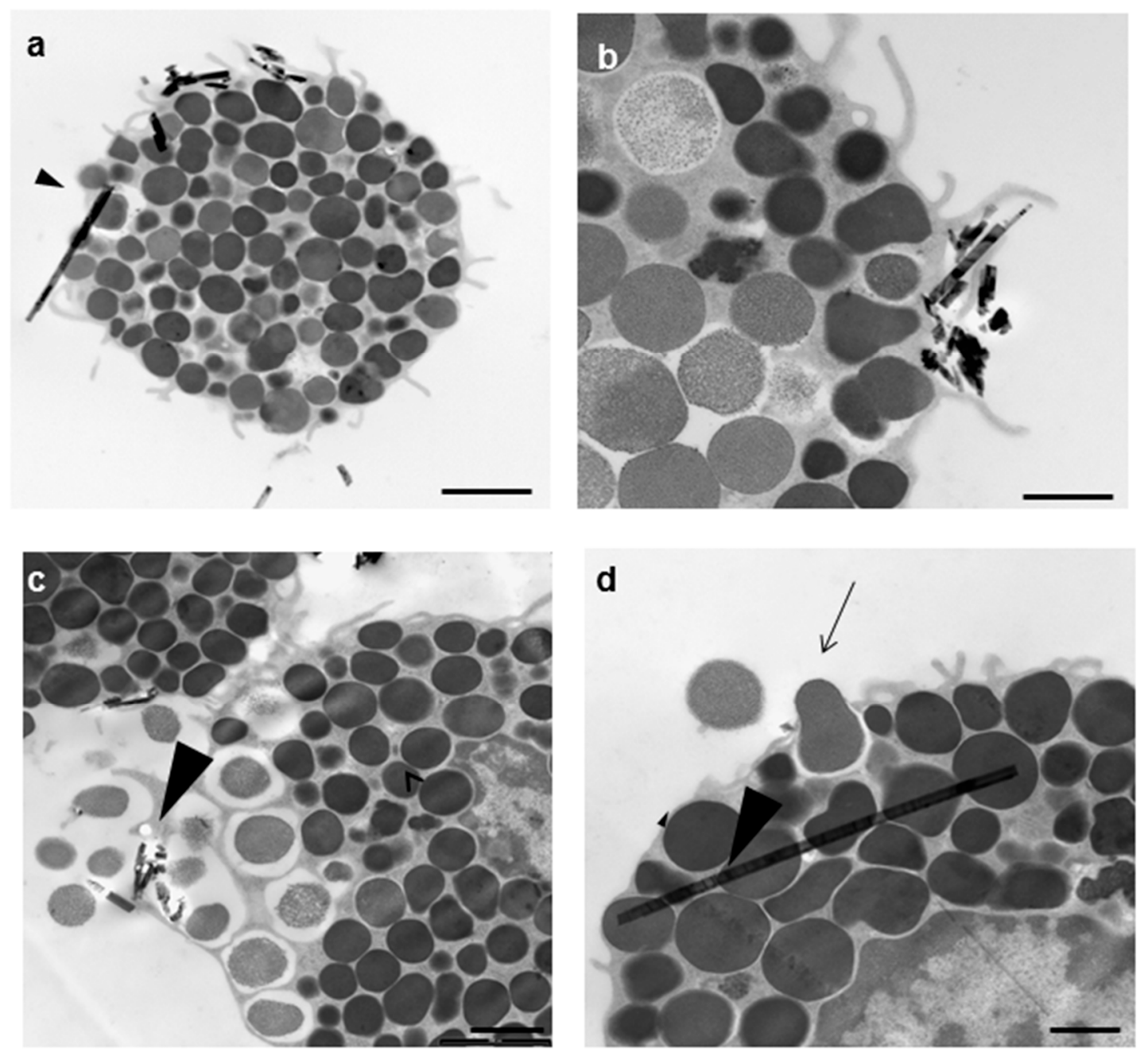

Figure 4. Transmission electron microscopy appearance of an RPMC exposed to $100 \mu \mathrm{g} / \mathrm{mL}$ of crocidolite fibers. After $30 \mathrm{~min}$ of incubation, the interacting fibers appear to undergo ingestion $(\mathbf{a}, \mathbf{b})$ or are free in the cytosol (arrowhead in $(\mathbf{a}, \mathbf{d})$ ); (c) a degranulation process is evident where asbestos fibers are present; (d) the RPMC releasing a single granule (arrow). Magnifications: bar in $(\mathbf{a})=2 \mu \mathrm{m}$; bar in (b) $=1 \mu \mathrm{m} ;(\mathbf{c})=2 \mu \mathrm{m} ;(\mathbf{d})=0.5 \mu \mathrm{m}$.

The morphological appearance of MCs stimulated by $\mathrm{CRO}$ or $\mathrm{TiO}_{2} \mathrm{NWs}$ suggests that a large amount of granule content has been secreted into the extracellular medium. To confirm this hypothesis, we analyzed the stimulated RPMC population for the presence of granule components in the incubation medium. 

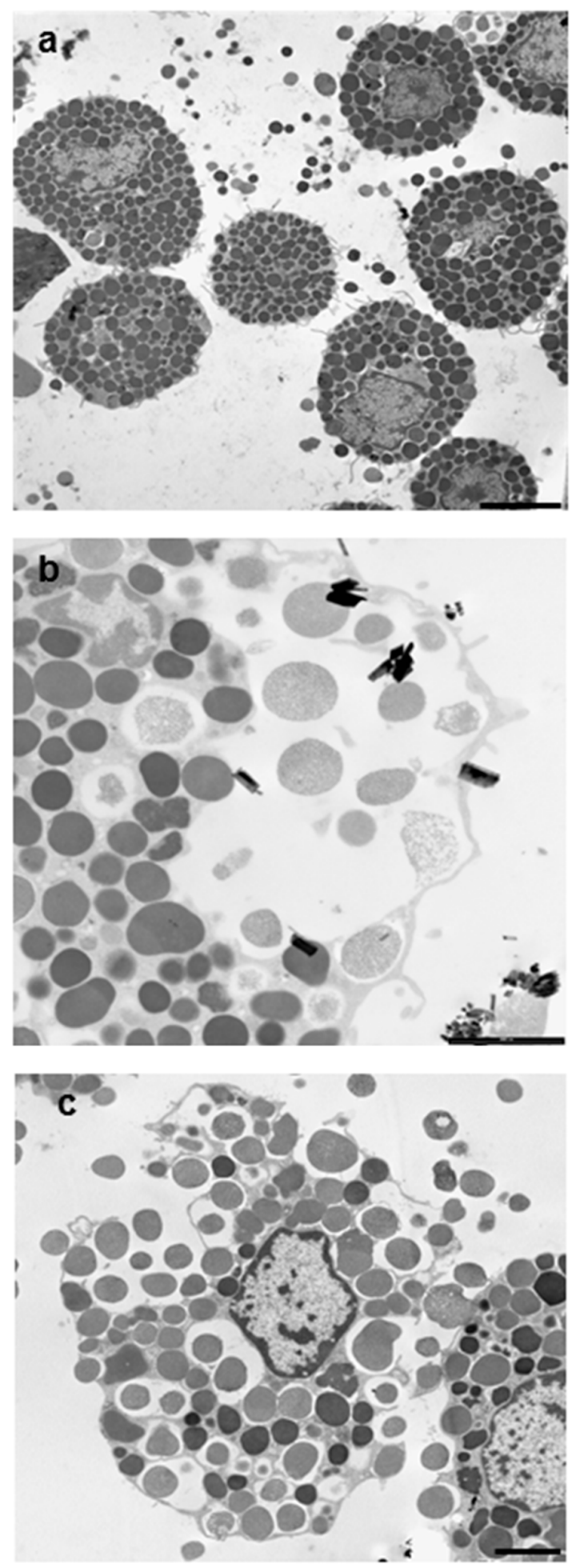

Figure 5. Transmission electron microscopy appearance of RPMC exposed to $100 \mu \mathrm{g} / \mathrm{mL}$ of crocidolite fibers. (a) The unstimulated RPMC population; (b,c) a crocidolite-stimulated RPMC. After 30 min of incubation the secretory process appears to follow two pathways. In some cases, the secretion appears to follow the conventional compound exocytosis pathway (b), which is characterized by multiple granule fusion and formation of large vacuoles, which will subsequently release the granule content in one step and give rise to granule remnants. On bottom right a granule remnant adhering to asbestos fibers is shown. In other cells the process follows cell disruption with intact granule expulsion (c). Magnifications: bar in $(\mathbf{a}, \mathbf{c})=2 \mu \mathrm{m}$. 


\subsection{Quantization of Secretion of Granules Components Induced by Mineral Fibers}

In order to monitor the secretory process induced in MCs by mineral fibers, we separated the supernatant of the stimulated cells from the cell pellet and measured the enzymatic activities of $\mathrm{CHY}$, a serine protease that accounts for half of the protein content of RPMC secretory granules (62), TRY, $\beta$-hexosaminidase ( $\beta$-hexo), and histamine, which are widely accepted markers of mast cell secretion (63).

Figure 6 shows that a potent secretion was elicited by $48 / 80$. A significant histamine release was found in the supernatant of RPMC challenged with CRO, but at a lower extent compared to 48/80. The other types of fibers elicited a weaker, but significant effect. However, despite the morphological appearance, the amount of soluble granule enzyme activity following incubation with fibers was not increased compared to that separated from unstimulated control (CTRL) cells. In the case of CHY and TRY, enzymatic activity was significantly lower $(p<0.05)$ while $\beta$-hexo appeared to be significantly released from RPMCs stimulated by $\mathrm{TiO}_{2} \mathrm{NWs}$ and WOLLA, but not by CRO (Table 1 ). This discrepancy may be explained by two possibilities: (1) an inhibitory effect exerted by the fibers on the enzymes; and/or (2) binding between fibers and either enzymes or intact granules. We therefore investigated whether asbestos fibers and $\mathrm{TiO}_{2} \mathrm{NWs}$ can bind and/or affect the activity of these enzymes. Figure $7 \mathrm{a}, \mathrm{b}$ show that mineral fibers cannot inhibit RPMC enzymes. Surprisingly, the lysate of mast cell exhibits a significant increase in $\mathrm{CHY}$ activity following an incubation of $30 \mathrm{~min}$ with $\mathrm{CRO}$. The incubation with WOLLA and $\mathrm{TiO}_{2} \mathrm{NWs}$ elicited a minor increment (on the average, not significant). Similarly, the activity of $\beta$-hexo and TRY was not significantly affected.

a
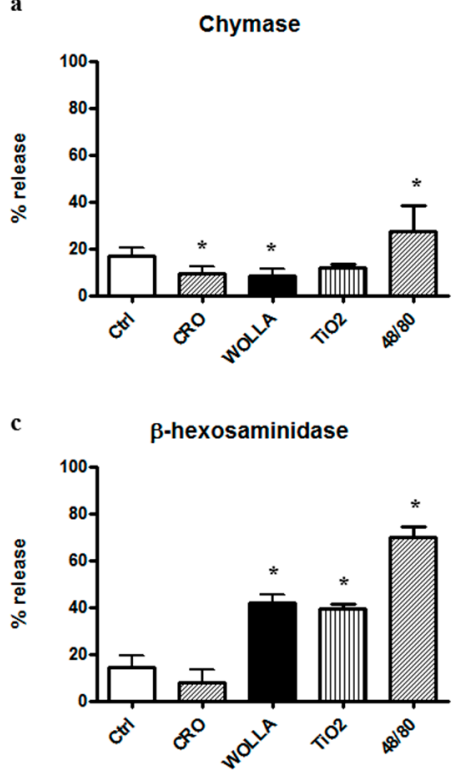

b

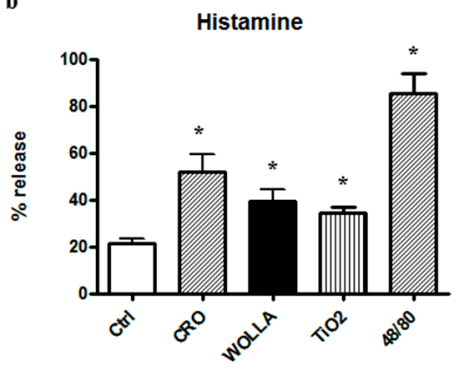

d

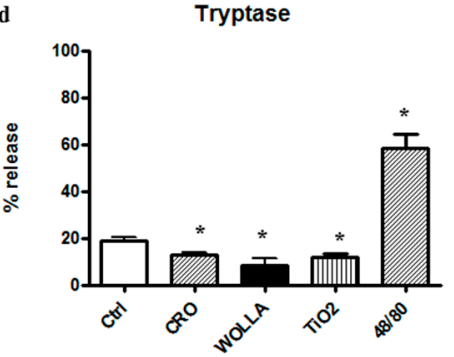

Figure 6. Enzyme secretion from mineral fiber $(100 \mu \mathrm{g} / \mathrm{mL})$ or $48 / 80$ compound $(10 \mu \mathrm{g} / \mathrm{mL})$-stimulated RPMCs. Values are the mean \pm SD of at least four different experiments. The extent of secretion, i.e., the percentage of enzyme activity in the supernatant, was calculated taking total enzyme activity (supernatant + pellet) as $100 \%$ (mean value \pm standard deviation (SD): $0.074 \pm 0.006$ for chymase, $0.079 \pm 0.006$ for $\beta$-hexosaminidase ( $\beta$-hexo) Optical Density (OD)/30 min and 0.060 $\pm 0.005 \mathrm{OD} / 30 \mathrm{~min}$ for tryptase). In the case of histamine, the total (supernatant + pellet) fluorescence arbitrary units were considered as $100 \%$. See text for details. In the case of $\beta$-hexosaminidase, the control value did not differ significantly from that obtained with crocidolite stimulation. In all other cases, the difference between control and stimulated (crocidolite or 48/80) values was significantly different $(p<0.05)$ (asterisks). CTRL $=$ control unstimulated cells; $\mathrm{Cro}=$ crocidolite-stimulated cells; Wolla $=$ wollastonite-stimulated cells; $\mathrm{TiO}_{2}=\mathrm{TiO}_{2} \mathrm{NW}$-stimulated cells; $48 / 80=48 / 80$-stimulated cells. 
a Chymase activity in whole lysate

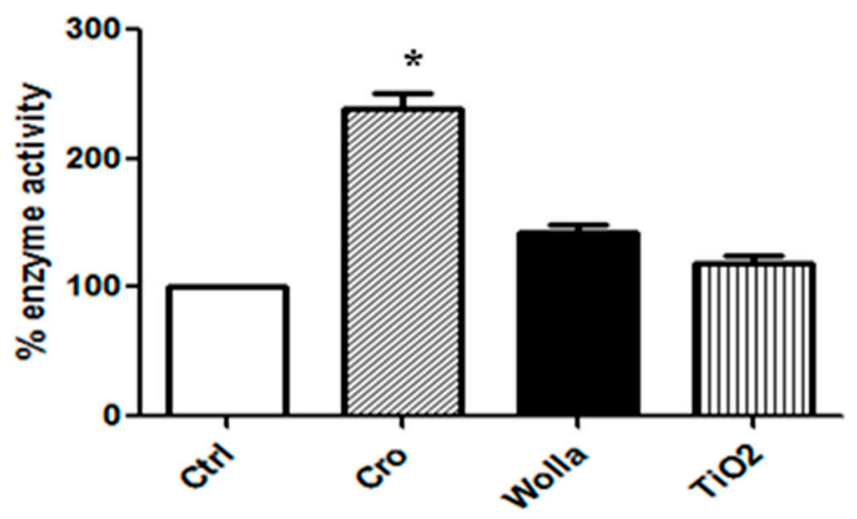

b $\beta$-hexosaminidase activity in whole lysate

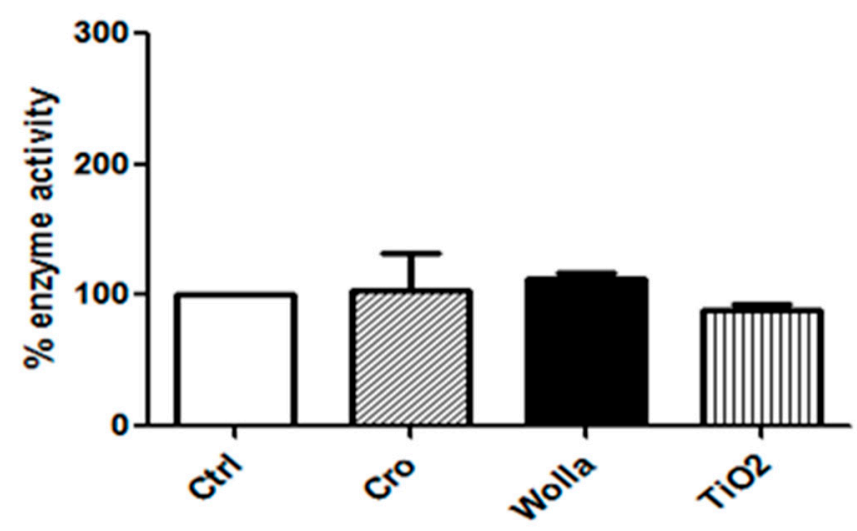

c Tryptase activity in whole lisate

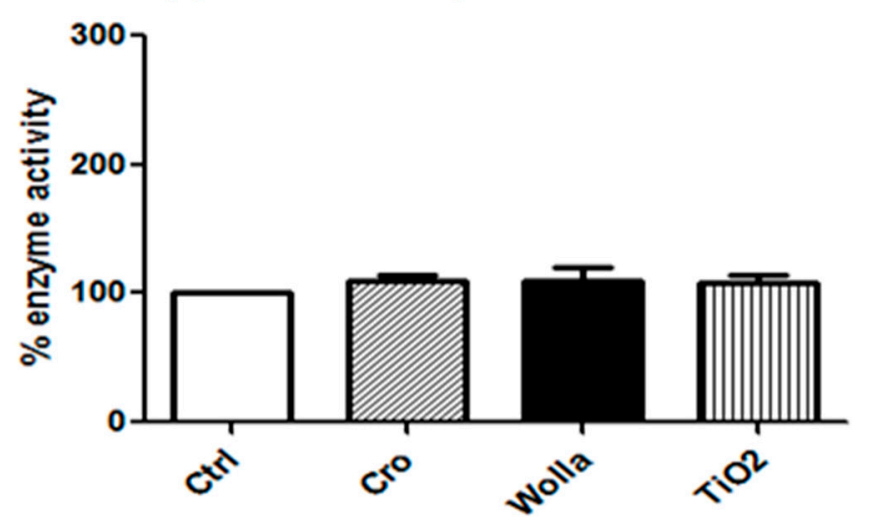

Figure 7. Effects of mineral fibers on enzyme activities in RPMC lysate. RPMC total lysate was obtained by sonication $\left(3 \times 10^{6} \mathrm{RPMC}\right.$ in $\left.1 \mathrm{~mL}\right)$ and incubated for $30 \mathrm{~min}$ with mineral fibers $(100 \mu \mathrm{g} / \mathrm{mL})$. The values reported are the mean \pm SD of at least five different experiments. The extent of enzyme activity was calculated taking the total enzyme activity present in the whole lysate as $100 \%$ $(0.390 \pm 0.052 \mathrm{OD} / 30 \mathrm{~min}$ for chymase; $0.160 \pm 0.080 \mathrm{OD} / 30 \mathrm{~min}$ for $\beta$-hexosaminidase; $0120 \pm 0.05$ OD/30 min for tryptase (TRY)). Significant differences $(p<0.05)$ between unstimulated lysate and lysate from RPMC exposed to mineral fibers are indicated by asterisks. CTRL $=$ unstimulated cells; $\mathrm{Cro}=$ crocidolite stimulated cells; Wolla $=$ wollastonite-stimulated cells; $\mathrm{TiO}_{2}=\mathrm{TiO}_{2} \mathrm{NW}$-stimulated cells; $48 / 80=48 / 80$-stimulated cells. 
Table 1. Summary of fiber-enzyme interactions.

\begin{tabular}{|c|c|c|c|c|c|c|c|c|c|c|c|c|c|}
\hline \multirow{3}{*}{$\begin{array}{l}\text { Isoelectric } \\
\text { Point }\end{array}$} & \multirow{3}{*}{ (IP) } & \multicolumn{4}{|c|}{ Chymase Activity } & \multicolumn{4}{|c|}{$\beta$-Hexosaminidase Activity } & \multicolumn{4}{|c|}{ Tryptase Activity } \\
\hline & & \multicolumn{4}{|c|}{9.6} & \multicolumn{4}{|c|}{$5.6-6.1$} & \multicolumn{4}{|c|}{$6.0-6.3$} \\
\hline & & CTRL & CRO & WOLLA & $\mathrm{TiO}_{2}$ & CTRL & CRO & WOLLA & $\mathrm{TiO}_{2}$ & CTRL & CRO & WOLLA & $\mathrm{TiO}_{2}$ \\
\hline RPMC & $\%$ Release & $16.5 \pm 3.8$ & $9.4 \pm 2.6^{*}$ & $8.2 \pm 3.2^{*}$ & $12.00 \pm 2.6$ & $14.2 \pm 5.2$ & $8.1 \pm 5.1$ & $41.0 \pm 3.6^{*}$ & $39.1 \pm 2.9^{*}$ & $19 \pm 3.0$ & $13.0 \pm 1.5$ & $8.0 \pm 2.0$ & $10.5 \pm 1.8$ \\
\hline \multirow[b]{2}{*}{ Lysate } & $\%$ increment & 100 & $238.5 \pm 19.6^{*}$ & $143.0 \pm 7.1$ & $125.0 \pm 7.1$ & 100 & $103.3 \pm 51.3$ & $112.0 \pm 7.0$ & $88.00 \pm 10.2$ & 100 & $125 \pm 6.0$ & $110 \pm 12.2$ & $105 \pm 5.0$ \\
\hline & $\begin{array}{l}\% \text { pellet } \\
\text { activity }\end{array}$ & $13.8 \pm 2.5$ & $86.5 \pm 7.7^{*}$ & $39.7 \pm 6.1 *$ & $36.2 \pm 10.1 *$ & $8.6 \pm 3.5$ & $93.6 \pm 4.1^{*}$ & $30.4 \pm 5.5^{*}$ & $12.9 \pm 4.0$ & nd & nd & nd & nd \\
\hline \multirow{2}{*}{$\begin{array}{l}\text { Human pure } \\
\text { enzymes }\end{array}$} & $\%$ increment & 100 & $224.9 \pm 44.6^{*}$ & $244.6 \pm 50.8^{*}$ & $244.7 \pm 8.3^{*}$ & nd & nd & nd & nd & 100 & $160 \pm 10.0$ & $97.0 \pm 12.0$ & $110.0 \pm 6.0$ \\
\hline & $\begin{array}{l}\text { \% pellet } \\
\text { activity }\end{array}$ & $8.1 \pm 2.1$ & $68.9 \pm 11.7^{*}$ & $61.8 \pm 1.9^{*}$ & $54.3 \pm 9.1 *$ & nd & nd & nd & nd & nd & nd & nd & nd \\
\hline
\end{tabular}

\% Release: refers to the amount of enzyme released from RPMCs after mineral fiber exposure found in the $250 \times g$ supernatant, taking the total amount of the RPMC enzyme as $100 \%$; $\%$ increment: refers to the percentage of increased enzyme activity in the presence of fibers taking the activity of the untreated enzyme as $100 \%$. The differences between resting lysate and lysate from RPMCs exposed to mineral fibers were statistically significant when indicated by asterisks $(p<0.05)$. IP: isoelectric point; nd: not determined. 
Having shown that crocidolite fibers induced significant improvement in the enzymatic activity of CHY in an RPMC lysate, we then investigated if the same effect could also be exerted on pure human enzymes. The data, summarized in Table 1 , show that $\mathrm{CRO}$, but also $\mathrm{TiO}_{2} \mathrm{NWs}$ and WOLLA, consistently increased the activity of pure human $\mathrm{CHY}$ and TRY, suggesting that the enhancing effect is not specific for the lysate-containing rat enzymes.

To assess if the increasing effect exerted by mineral fibers can be ascribed to the isoelectric point (IP) of the protein molecule (about 6.0-6.3 for $\beta$-hexo and TRY and 9.6 for chymase), which could influence the fiber-associating trend, we assayed the enzymatic activity of human myeloperoxidase (MPO IP, 9.3) and human eosinophil peroxidase (EPO IP, 10.8) after $30 \mathrm{~min}$ incubation with mineral fibers. We found that MPO activity was only weakly increased (see Supplementary Figure S8a), reaching its maximum when incubated with $\mathrm{TiO}_{2} \mathrm{NWs}$, while that of EPO was significantly enhanced (Supplementary Figure S8b) specifically after incubation with crocidolite and $\mathrm{TiO}_{2} \mathrm{NWs}$. These results suggest that the IP of the considered enzymes is not directly related to the increase of activity induced by fibers.

These results prompted us to evaluate the enzyme-binding capacity of mineral fibers directly by incubating them with either whole RPMC lysate or purified enzymes and monitoring the enzyme activities in the $250 \times g$ pellet.

Figure $8 \mathrm{a}-\mathrm{d}$ show that the main enzyme activities in the unstimulated lysate were soluble and only a small amount was found in the $250 \times g$ pellet fraction, presumably due to the fact that some granules or cell aggregates escaped complete disruption. In contrast, the activity of both $\beta$-hexo and $\mathrm{CHY}$ were mainly found in CRO-containing pellets $(86.5 \%$ and $93.6 \%$ respectively), indicating that these fibers are able to absorb both enzymes. However, the other two types of fibers also bind rat $\mathrm{CHY}$ and $\beta$-hexo. As much as $39.7 \%$ and $36.2 \%$ of the CHY activity was found in the WOLLA and $\mathrm{TiO}_{2} \mathrm{NW}$ pellets, respectively. While $30.4 \%$ of $\beta$-hexo activity was found in the WOLLA pellet, only a small fraction $(12.9 \%)$ of this enzyme was found in the $\mathrm{TiO}_{2} \mathrm{NW}$ pellet. Comparable findings were obtained when assaying pure human chymase activity. In this case, all three types of mineral fibers were able to drag a consistent amount of the enzyme activity (over 50\%) in the pellet fraction. All these data are summarized in Table 1.
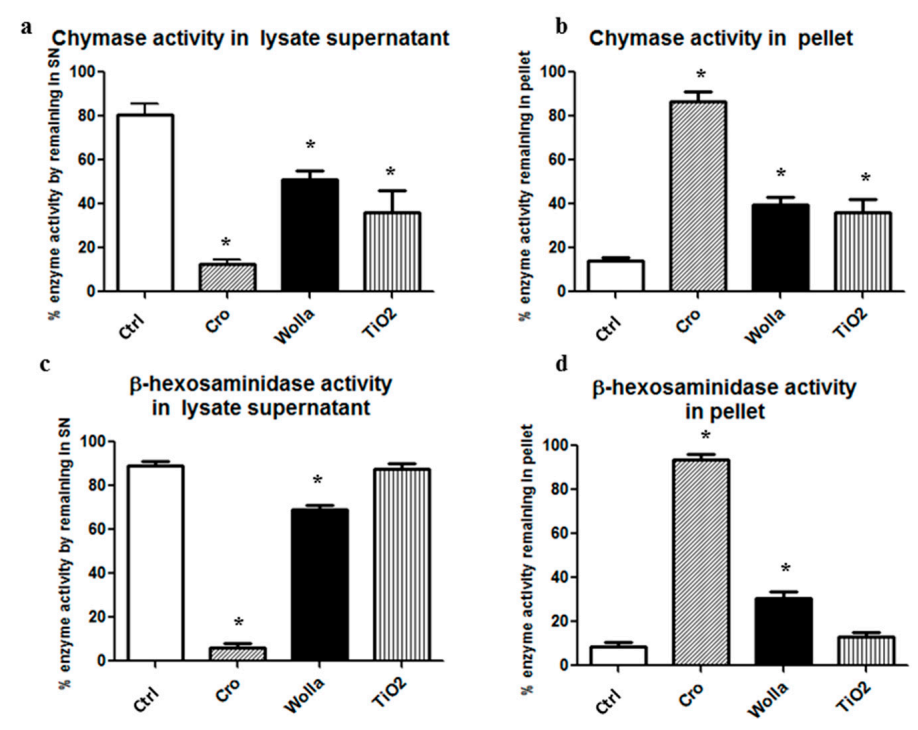

Figure 8. Extent of RPMC lysate enzyme absorption on mineral fibers. After 30 min incubation of the lysate in the presence of fibers $(100 \mu \mathrm{g} / \mathrm{mL})$, the supernatant was obtained by centrifuging the mixture at $250 \times g$ for $15 \mathrm{~min}$ at $4{ }^{\circ} \mathrm{C}$. $(\mathbf{a}, \mathbf{b})$ fractionation of chymase activity; (c,d) fractionation of $\beta$-hexosaminidase activity. Significant changes in activity in the samples exposed to mineral fibers vs. baseline value (see the legend to Figure 7) are indicated by asterisks $(p<0.05)$. $\mathrm{CTRL}=$ control unstimulated cells; $\mathrm{Cro}=$ crocidolite-exposed enzyme; Wolla $=$ wollastonite-exposed enzyme; $\mathrm{TiO}_{2}=\mathrm{TiO}_{2} \mathrm{NW}$-exposed enzyme. 


\section{Discussion}

Herein, we describe the outcome of the interaction between mast cells and mineral fibers. For this purpose, we chose crocidolite, a type of asbestos which is thought to be the most active and whose mechanism of cell interaction is not yet completely clear, and $\mathrm{TiO}_{2}$ nanowires, which are considered to be a more active form of titanium oxide and whose industrial applications are increasing. Even for the latter, the mechanism of interaction with inflammatory cells is still only partially known. However, $\mathrm{TiO}_{2} \mathrm{NPs}$ are thought to be very promising for the development of new technologies [3] and are expected to be released in the environment in relatively large amounts due to their widespread use in photovoltaic cells, photoelectrolizers, and other applications.

Light microscopy analysis of the secretory process of RPMC was quickly activated after $5 \mathrm{~min}$ of incubation with crocidolite. This is comparable to the potent stimulus induced by the $48 / 80$ compound. $\mathrm{TiO}_{2} \mathrm{NWs}$ also stimulate mast cell degranulation, but after a longer incubation period, while as expected WOLLA represents a weaker RPMC stimulus. Following $\mathrm{TiO}_{2} /$ crocidolite-induced degranulation, the granules appear to adhere to the stimulating fibers.

This granule-to-fiber adhesion can be also induced by incubating isolated membrane-covered RPMC granules with crocidolite. The scanning electron microscopy appearance of stimulated MCs strongly suggests that both crocidolite fibers and $\mathrm{TiO}_{2} \mathrm{NWs}$ induce a significant secretory reaction, although to a different extent, thus confirming the preliminary light microscopy findings. SEM analysis also confirmed free granule adhesion to the mineral fibers (see Figures 2 and 3) and suggests that this adhesion, which resists to all the procedures for preparing SEM samples is consistent.

Some CRO fibers are completely covered/surrounded by the cell membrane, while others protrude from the cell, as would be expected if they had pierced the cell. The detailed TEM analysis of RPMC-CRO interaction suggests two possible pathways for fiber-membrane interaction: one could be via the conventional mechanism of phagocytosis, entailing adhesion to the plasma membrane and subsequent engulfment, as reported for macrophages and other cells; the second, which has already been suggested by some authors, including ourselves, is the passive fiber-dependent piercing of the RPMC membrane resulting in the presence of nude fibers in the cytosol without any surrounding membrane. This penetration pathway has already been demonstrated, and is now widely accepted, to be the main one for $\mathrm{TiO}_{2} \mathrm{NWs}$ and NPs $[4,6,15]$. The interaction between asbestos fibers and cell membranes has been under investigation since the 1980s [86-90]. In general terms, it is thought that the first interaction between macrophages and asbestos fibers occurs through a phagocytic process [36], which does not exclude the possibility that the ingested fibers may exit from the phagosome into the cytosol and even enter the nuclear compartment [51,91,92], nor that passive entry of fibers through the cell membrane may occur at the same time [31,91]. Despite all this evidence, the mechanism of interaction of asbestos fibers with cell membrane phospholipids and how this influences cell membrane and intracellular organelle properties is still a matter of debate. Our findings show, for the first time, that in addition to being entrapped by pseudopodia (as in a conventional phagocytic process), fibers can also access the cell cytosol in another way. Even if the relative mechanism remains unknown, we suggest that they can passively pierce the MC membrane. While the former type of interaction could be specific and trigger a conventional secretory process, the latter could be lethal for cells, eventually leading to their disruption and to the passive release of all their granules. Direct evidence supporting a piercing action of the fiber is presently missing, but monitoring of the CRO fiber inside the cell for 120-720 nm shows that the fiber is without doubt inside the cell without any surrounding membranes (Supplementary Figures S5-S7). Further research must be carried out to investigate the mechanism that allows cytosolic subcellular localization of mineral fibers.

The ultrastructural analysis of the RPMC-CRO interaction shows that the secretory process can be carried out via two possible pathways: active secretion with single granule secretion, and conventional compound exocytosis, both of which cause progressive release of granule content and formation of granule remnants, and passive expulsion of membrane-covered granules due to plasmamembrane rupture. Our findings suggest that both these granule structures can adhere to mineral fibers, but very 
likely it is the latter that mainly adhere. This finding also suggests that the main pathway of "secretion" is realized via granule expulsion rather than active secretion.

The finding that the analysis by both SEM and TEM shows the extent of granule extrusion/secretion to be lower than that observed by light microscopy is probably due to the more conservative procedures employed in the processing for electron microscope analysis compared to the more disruptive procedures employed for preparation of cytocentrifuge specimens. We suspect that RPMCs may become more susceptible to disruption as a result of mechanical stress (cytocentrifugation) following exposure to mineral fibers.

As expected, histamine release was in agreement with the morphological appearance of fiber-challenged RPMCs. Conversely, despite this, the extracellular release of granular enzymes in CRO-stimulated RPMCs was not higher from that found in unstimulated control (CTRL) cells (and in the case of CHY and TRY was even significantly lower). Apparently, $\mathrm{TiO}_{2} \mathrm{NWs}$ and WOLLA acted as a stimulus only for $\beta$-hexo release. In the case of WOLLA, this finding is in contrast with the morphological analysis, according to which only a very weak secretion, if any, is induced by this mineral fiber. This discrepancy could be explained by the different subcellular localization of the secretory granule components (CHY) and secretory lysosome enzymes ( $\beta$-hexo) [93]. The two compartments could follow different pathways of secretion, with the latter being mobilized specifically by WOLLA. On the basis of morphological analysis, we think it likely that CRO and $\mathrm{TiO}_{2} \mathrm{NWs}$ are, conversely, able to mobilize all secretory compartments, including granules and lysosomes. These findings were not investigated further as this would have required a series of dedicated experiments.

We excluded that the discrepancy between morphological and enzymatic analysis of the degranulation process could be ascribed to an inhibitory effect exerted by mineral fibers on soluble enzymes. On the contrary, we found that CRO significantly enhanced RPMC CHY activity, while the two other types of mineral fiber had a weaker (non-significant) activity-enhancing effect on this enzyme in RPMC lysates. Similar to the effect observed in the rat enzyme, human pure chymase activity was also significantly increased by all three fiber types. Of note, human tryptase activity was also increased by incubation with CRO. We believe it is likely that enzymatic activity enhancement may require enzyme-fiber absorption as a necessary, albeit not sufficient, step. The high isoelectric point of CHY and EPO (whose activities are greatly enhanced) vs. low IP value of $\beta$-hexo (whose activity shows weak or no enhancement), would lend support to this hypothesis. However, an electrostatic interaction cannot be the only feature involved. Firstly, the activity of MPO, which has a high IP (IP 9.3), appears to be only marginally increased; secondly, chymase is released together with heparin [94], so that the electrostatic charge of the complex is not that of the pure protein. It would be of interest to investigate the effects of the presence of heparin in the interaction between CRO and chymase. Other factors besides IP, such as molecular weight of the interacting protein and/or fiber zeta-potential, could be involved. As far as tryptase is concerned, we found that while the rat enzyme is only very weakly affected by incubation with the fibers, the human protein is significantly enhanced when incubated with crocidolite. This finding also supports a role of human mast cell protease in the pathological events induced by mineral fiber inhalation.

Taken together, these results indicate that, in the case of $\mathrm{CRO}$ and $\mathrm{TiO}_{2}$, the low activity of the granular enzyme found extracellularly, as opposed to the consistent degranulation shown by the morphological analysis and histamine release, could depend on a significant adsorption of the soluble released enzyme on the fiber and, secondly, on the binding of the granules to the fibers, which drags down the granule structures with all or part of their content. The finding that histamine, which is actually free in solution, is not bound by all the types of fibers under our experimental conditions (not shown) supports this possibility.

WOLLA, a weak stimulus for degranulation, is also able to bind soluble enzymes, thereby probably sequestering small amounts of them even from the unstimulated RPMC supernatant, but 
fails to bind whole granules, as shown by ultrastructural analysis. These findings suggest that different mechanisms underlie the fiber-binding capacity for soluble enzymes and membrane-covered granules.

We present herein evidence that asbestos fibers, and to a lesser extent $\mathrm{TiO}_{2} \mathrm{NWs}$, are potent stimuli for MC granule secretion. Morphological evidence suggests that the fiber-cell interaction can induce cell membrane stimulus/injury, followed by the secretion of granule content or of whole granules. In either case, granular structures and/or soluble enzymes can bind to fibers and coat them. It must be noted that, as mineral fibers can sequester both granules and enzymes (or enzymes only in the case of WOLLA) at the same time, it is very difficult to quantitate precisely the amount of enzyme secreted using conventional criteria.

The improvement of the properties of immobilized protein is a well-known process. Enzymes loaded on a carrier display prolonged half-life, improved stability, and acquire a range of specific advantages, such as broad optimal $\mathrm{pH}$ and temperature range [95]. A similar improvement of the properties of immobilized chymase could explain the higher enzymatic activity of this protein observed in our experiments. We think it is possible that the granule content is continuously solubilized from the granule and recaptured / bound again by the fiber. Chymase, which displayed both an activity-enhancing effect and high fiber-binding capacity, may significantly increase the pro-inflammatory capacity of mineral fibers (particularly of asbestos). More specifically, chymase can activate IL-1 $\beta$ and potentiate the effect of histamine [96], as well as degrade IL-33, giving rise to mature forms with a potent effect on innate lymphoid cells [97], and eventually degrading it completely [98]. The activity of these IL-1 family members should improve when the peptidase activity of mast cells bound to mineral (particularly asbestos) fibers is stimulated. We also expect the activity of immobilized enzymes to become more stable, which would contribute to their prolonged proinflammatory capacity. Notably, $\mathrm{TiO}_{2}$, which has already been used to immobilize enzymes, and wollastonite are able to bind a variety of enzymes and improve their activity. However, their capacity in this sense is significantly lower than that of crocidolite. Since asbestos fibers persist in human lung and pleura [99] together with MC [65] for decades, the granule/enzyme-enriched fibers induced by both $\mathrm{CRO}$ and $\mathrm{TiO}_{2}$, could prolong their activity over long periods of time. Data on the toxicity of nanowires are still very limited. Our results suggest that certain nanowires, such as $\mathrm{TiO}_{2} \mathrm{NWs}$, may present health risks similar to those posed by asbestos fibers. Therefore, it is important that the toxicity of all inorganic nanofilaments are systematically assessed before fully allowing their industrial application and mass production.

These results highlight the critical role that MCs may play in the pathogenesis of mineral fiber-related diseases. Mast cells (either mucosal and connective tissue type) are present in human airways [67]. This cell population is equipped with histamine, tryptase, and chymase, which following mineral fiber-induced release may be involved in progression of fibrosis and the inflammatory process. Our model focusing on RPMCs, which are of the connective type (MCct), cannot directly demonstrate the involvement of human mast cells in these pathological events, which are typical of mineral fiber-induced disease. However, the findings that: (1) Th2 response is active in exposed subjects; (2) both human and rat MC protease (CHY and TRY) activities are improved by the contact with mineral fibers, particularly asbestos; and (3) in the human airway MCct are present [67], together suggest that RPMCs could be a valid surrogate of human mast cells of the connective type and that the latter may also be involved in mineral fiber-induced pathology in humans. However, further experiments in an animal model are needed to directly investigate the proinflammatory role played by protease-coated fibers vs their uncoated counterparts. In this model, we can also evaluate the long-term (months) effect of mineral fibers on cytokine expression, synthesis, and release. Such granule/enzyme-enriched fibers resemble mast cell extracellular traps (MCETs) [100], which are known to increase and maintain a pro-inflammatory stimulus in tissues. We suggest that the stimulus of Th2 immunity exerted by the crocidolite fibers and, to a lower extent by $\mathrm{TiO}_{2} \mathrm{NPs}$, can be ascribed to the outcomes of the fiber-mast cell interaction described herein, and that this interaction should be considered for the identification of new therapeutic targets to treat exposed subjects. 


\section{Conclusions}

In conclusion, the novel findings reported in this paper can be summarized as follows:

1. Mineral fibers are a potent stimulus for the mast cell secretory process, through both active (during membrane interaction) and passive (during cytosolic penetration) interactions. The rank order is: $\mathrm{CRO}>\mathrm{TiO}_{2} \mathrm{NW}>>$ WOLLA. We demonstrate by serial sections at TEM analysis that the cytosolic inclusion of asbestos fibers is not an artifact, but that they are actually inside the cell. We therefore speculate that the presence of fibers inside the cytosol may be toxic and trigger cell rupture and granule expulsion. Of note, $\mathrm{TiO}_{2}$ nanoparticles were also found inside the cytosol without any surrounding membrane.

2. Tissue-deposited fibers can aggregate large amounts of pro-inflammatory factors by binding free enzymes, intact granules, and granule remnants. Deposited fibers can continue to bind granules from MCs as cells are renewed and more fibers are inhaled, thereby creating a long-lasting pro-inflammatory environment.

3. MCs could contribute to the inflammatory and toxic effects associated with some engineered nanomaterials, including $\mathrm{TiO}_{2} \mathrm{NPs}$, which are widely used and are therefore a cause of increasing concern for their potential to harm humans.

Supplementary Materials: The following are available online at www.mdpi.com/1660-4601/15/1/104/s1, Figure S1: Crocidolite characterization by ultrastructural and EDX analysis; Figure S2: Titanium dioxide nanowire characterization by ultrastructural and EDX analysis; Figure S3: Wollastonite characterization by ultrastructural and EDX analysis; Figure S4: Scanning electron microscope appearance of membrane-covered granules and granule remnants; Figure S5: Serial sections of the same RPMC spanning $120 \mathrm{~nm}$ in depth; Figure S6: Serial sections of the same RPMC spanning $720 \mathrm{~nm}$ in depth; Figure S7: Serial sections of the same rat peritoneal eosinophil spanning $300 \mathrm{~nm}$ in depth; Figure S8: Effects of the interaction of mineral fibers with pure human peroxidases.

Acknowledgments: We would like to thank Alessandra Knowles for helping to revise the manuscript. This work was supported by a grant from Beneficentia Stiftung (Vaduz, Liechtenstein).

Author Contributions: Violetta Borelli designed and coordinated the study, was substantially involved in experiments, acquisition, analysis, and interpretation of results, and drafted the manuscript. Elisa Trevisan performed the experiments and revised the manuscript with respect to methodological aspects. Francesca Vita provided SEM and TEM analyses and interpretation. Giuliano Zabucchi directed the work and critically revised the manuscript.

Conflicts of Interest: The authors declare no conflict of interest. The founding sponsors had no role in the design of the study; in the collection, analyses, or interpretation of data; in the writing of the manuscript, and in the decision to publish the results.

$\begin{array}{ll}\text { Abbreviations } \\ \text { BSA } & \text { bovine serum albumin } \\ \mathrm{MCs} & \text { mast cells } \\ \text { RPMCs } & \text { rat peritoneal mast cells } \\ \beta \text {-hexo } & \beta \text {-hexosaminidase } \\ \mathrm{CHY} & \text { chymase } \\ \mathrm{TRY} & \text { tryptase } \\ \mathrm{CRO} & \text { crocidolite } \\ \mathrm{TiO} 2 & \text { titanium oxide } \\ \mathrm{NWs} & \text { nanowires } \\ \mathrm{NPs} & \text { nanoparticles } \\ \mathrm{WOLLA} & \text { wollastonite fibers } \\ \mathrm{NLRP3} & \text { NLR pyrin domain-containing } 3 \\ \text { PBS } & \text { phosphate buffered saline } \\ \mathrm{SEM} & \text { scanning electron microscope } \\ \mathrm{TEM} & \text { transmission electron microscope } \\ \mathrm{IP} & \text { isoelectric point }\end{array}$




$\begin{array}{ll}\text { hMPO } & \text { human myeloperoxidase } \\ \text { hEPO } & \text { eosinophil peroxidase } \\ \text { MCETs } & \text { mast cell extracellular traps } \\ \text { TMB } & 3,3^{\prime}, 5,5^{\prime} \text {-Tetramethylbenzidine } \\ \text { TB } & \text { trypan blue } \\ \text { SN } & \text { supernatant } \\ \text { P } & \text { pellet } \\ \text { ROS } & \text { reactive oxygen species }\end{array}$

\section{References}

1. Novello, S.; Pinto, C.; Torri, V.; Porcu, L.; Di Maio, M.; Tiseo, M.; Ceresoli, G.; Magnani, C.; Silvestri, S.; Veltri, A.; et al. The Third Italian Consensus Conference for Malignant Pleural Mesothelioma: State of the art and recommendations. Crit. Rev. Oncol. Hematol. 2016, 104, 9-20. [CrossRef] [PubMed]

2. Ferin, J.; Oberdörster, G.; Penney, D.P. Pulmonary retention of ultrafine and fine particles in rats. Am. J. Respir. Cell Mol. Biol. 1992, 6, 535-542. [CrossRef] [PubMed]

3. Magrez, A.; Horváth, L.; Smajda, R.; Salicio, V.; Pasquier, N.; Forró, L.; Schwaller, B. Cellular toxicity of $\mathrm{TiO}_{2}$-based nanofilaments. ACS Nano 2009, 3, 2274-2280. [CrossRef] [PubMed]

4. Park, E.J.; Shim, H.W.; Lee, G.H.; Kim, J.H.; Kim, D.W. Comparison of toxicity between the different-type $\mathrm{TiO}_{2}$ nanowires in vivo and in vitro. Arch. Toxicol. 2013, 87, 1219-1230. [CrossRef] [PubMed]

5. Wang, J.; Fan, Y. Lung Injury Induced by $\mathrm{TiO}_{2}$ Nanoparticles Depends on Their Structural Features: Size, Shape, Crystal Phases and Surface Coating. Int. J. Mol. Sci. 2014, 15, 22258-22278. [CrossRef] [PubMed]

6. Hamilton, R.F.; Wu, N.; Porter, D.; Buford, M.; Wolfarth, M.; Holian, A. Particle length-dependent titanium dioxide nanomaterials toxicity and bioactivity. Part. Fiber Toxicol. 2009, 6, 35. [CrossRef] [PubMed]

7. Vuong, N.Q.; Goegan, P.; Mohottalage, S.; Breznan, D.; Ariganello, M.; Williams, A.; Elisma, F.; Karthikeyan, S.; Vincent, R.; Kumarathasan, P. Proteomic changes in human lung epithelial cells (A549) in response to carbon black and titanium dioxide exposures. J. Proteom. 2016, 21, 53-63. [CrossRef] [PubMed]

8. Allegri, M.; Bianchi, M.G.; Chiu, M.; Varet, J.; Costa, A.L.; Ortelli, S.; Blosi, M.; Bussolati, O.; Poland, C.A.; Bergamaschi, E. Shape-Related Toxicity of Titanium Dioxide Nanofibres. PLoS ONE 2016, 11, e0151365. [CrossRef] [PubMed]

9. Ohyama, M.; Otake, T.; Morinaga, K. Effect of Size of Man-Made and Natural Mineral Fibers on Chemiluminescent Response in Human Monocyte-Derived Macrophages. Environ. Health Perspect. 2001, 109, 1033-1038. [CrossRef] [PubMed]

10. Vergaro, V.; Aldieri, E.; Fenoglio, I.; Marucco, A.; Carlucci, C.; Ciccarella, G. Surface reactivity and in vitro toxicity on human bronchial epithelial cells (BEAS-2B) of nanomaterials intermediates of the production of titania-based composites. Toxicology 2016, 34, 171-178. [CrossRef] [PubMed]

11. Watanabe, M.; Okada, M.; Kudo, Y.; Tonori, Y.; Niitsuya, M.; Sato, T.; Aizawa, Y.; Kotani, M. Differences in the effects of fibrous and particulate titanium dioxide on alveolar macrophages of Fischer 344 rats. J. Toxicol. Environ. Health A 2002, 65, 1047-1060. [CrossRef] [PubMed]

12. Hong, J.; Wang, L.; Zhao, X.; Yu, X.; Sheng, L.; Xu, B.; Liu, D.; Zhu, Y.; Long, Y.; Hong, F. Th2 factors may be involved in $\mathrm{TiO}_{2} \mathrm{NP}$-induced hepatic inflammation. J. Agric. Food Chem. 2014, 62, 6871-6878. [CrossRef] [PubMed]

13. Eom, Y.; Song, J.S.; Lee, H.K.; Kang, B.; Kim, H.C.; Lee, H.K.; Kim, H.M. The Effect of Ambient Titanium Dioxide Microparticle Exposure to the Ocular Surface on the Expression of Inflammatory Cytokines in the Eye and Cervical Lymph Nodes. Investig. Ophthalmol. Vis. Sci. 2016, 57, 6580-6590. [CrossRef] [PubMed]

14. Jain, A.K.; Senapati, V.A.; Singh, D.; Dubey, K.; Maurya, R.; Pandey, A.K. Impact of anatase titanium dioxide nanoparticles on mutagenic and genotoxic response in Chinese hamster lung fibroblast cells (V-79): The role of cellular uptake. Food Chem. Toxicol. 2017, 105, 127-139. [CrossRef] [PubMed]

15. Fage, S.W.; Muris, J.; Jakobsen, S.S.; Thyssen, J.P. Titanium: A review on exposure, release, penetration, allergy, epidemiology, and clinical reactivity. Contact Dermat. 2016, 74, 323-345. [CrossRef] [PubMed]

16. Pelclova, D.; Zdimal, V.; Kacer, P.; Fenclova, Z.; Vlckova, S.; Komarc, M.; Navratil, T.; Schwarz, J.; Zikova, N.; Makes, O.; et al. Leukotrienes in exhaled breath condensate and fractional exhaled nitric oxide in workers exposed to $\mathrm{TiO}_{2}$ nanoparticles. J. Breath Res. 2016, 10, 036004. [CrossRef] [PubMed] 
17. Pelclova, D.; Zdimal, V.; Kacer, P.; Zikova, F.; Komarc, M.; Fenclova, Z.; Vlckova, S.; Schwarz, J.; Makeš, O.; Syslova, K.; et al. Markers of lipid oxidative damage in the exhaled breath condensate of nano $\mathrm{TiO}_{2}$ production workers. Nanotechnology 2017, 11, 52-63. [CrossRef] [PubMed]

18. Kang, C.M.; Jang, A.S.; Ahn, M.H.; Shin, J.A.; Kim, J.H.; Choi, Y.S.; Rhim, T.Y.; Park, C.S. Interleukin-25 and interleukin-13 production by alveolar macrophages in response to particles. Am. J. Respir. Cell Mol. Biol. 2005, 33, 290-296. [CrossRef] [PubMed]

19. Östberg, A.K.; Dahlgren, U.; Sul, Y.T.; Johansson, C.B. Inflammatory cytokine release is affected by surface morphology and chemistry of titanium implants. J. Mater. Sci. Mater. Med. 2015, 26, 155. [CrossRef] [PubMed]

20. Kumar, S.; Meena, R.; Paulraj, R. Role of Macrophage (M1 and M2) in Titanium-Dioxide Nanoparticle-Induced Oxidative Stress and Inflammatory Response in Rat. Appl. Biochem. Biotechnol. 2016, 180, 1257-1275. [CrossRef] [PubMed]

21. Yanagisawa, R.; Takano, H.; Inoue, K.; Koike, E.; Kamachi, T.; Sadakane, K.; Ichinose, T. Titanium dioxide nanoparticles aggravate atopic dermatitis-like skin lesions in NC/Nga mice. Exp. Biol. Med. 2009, 234, 314-322. [CrossRef] [PubMed]

22. Larsen, S.T.; Roursgaard, M.; Jensen, K.A.; Nielsen, G.D. Nano titanium dioxide particles promote allergic sensitization and lung inflammation in mice. Basic Clin. Pharmacol. Toxicol. 2010, 106, 114-117.

23. Mishra, V.; Baranwal, V.; Mishra, R.K.; Sharma, S.; Paul, B.; Pandey, A.C. Titanium dioxide nanoparticles augment allergic airway inflammation and Socs3 expression via NF- $\kappa$ B pathway in murine model of asthma. Biomaterials 2016, 92, 90-102. [CrossRef] [PubMed]

24. Ahn, M.H.; Kang, C.M.; Park, C.S.; Park, S.J.; Rhim, T.; Yoon, P.O.; Chang, H.S.; Kim, S.H.; Kyono, H.; Kim, K.C. Titanium dioxide particle-induced goblet cell hyperplasia: Association with mast cells and IL-13. Respir. Res. 2005, 13, 34. [CrossRef] [PubMed]

25. Fu, Y.; Zhang, Y.; Chang, X.; Zhang, Y.; Ma, S.; Sui, J.; Yin, L.; Pu, Y.; Liang, G. Systemic immune effects of titanium dioxide nanoparticles after repeated intratracheal instillation in rat. Int. J. Mol. Sci. 2014, 15, 6961-6973. [CrossRef] [PubMed]

26. Chang, X.; Fu, Y.; Zhang, Y.; Tang, M.; Wang, B. Effects of Th1 and Th2 cells balance in pulmonary injury induced by nano titanium dioxide. Environ. Toxicol. Pharmacol. 2014, 37, 275-283. [CrossRef] [PubMed]

27. Huang, C.; Sun, M.; Yang, Y.; Wang, F.; Ma, X.; Li, J.; Wang, Y.; Ding, Q.; Ying, H.; Song, H.; et al. Titanium dioxide nanoparticles prime a specific activation state of macrophages. Nanotoxicology 2017, 15, 1-14. [CrossRef] [PubMed]

28. Geiser, M.; Rothen-Rutishauser, B.; Kapp, N.; Schürch, S.; Kreyling, W.; Schulz, H.; Semmler, M.; Im Hof, V.; Heyder, J.; Gehr, P. Ultrafine particles cross cellular membranes by nonphagocytic mechanisms in lungs and in cultured cells. Environ. Health Perspect. 2005, 113, 1555-1560. [CrossRef] [PubMed]

29. Singh, S.; Shi, T.; Duffin, R.; Albrecht, C.; van Berlo, D.; Höhr, D.; Fubini, B.; Martra, G.; Fenoglio, I.; Borm, P.J.; et al. Endocytosis, oxidative stress and IL-8 expression in human lung epithelial cells upon treatment with fine and ultrafine $\mathrm{TiO}_{2}$ : Role of the specific surface area and of surface methylation of the particles. Toxicol. Appl. Pharmacol. 2007, 222, 141-151. [CrossRef] [PubMed]

30. Malorni, W.; Iosi, F.; Falchi, M.; Donelli, G. On the mechanism of cell internalization of chrysotile fibers: An immunocytochemical and ultrastructural study. Environ. Res. 1990, 52, 164-177. [CrossRef]

31. Andolfi, L.; Trevisan, E.; Zweyer, M.; Prato, S.; Troian, B.; Vita, F.; Borelli, V.; Soranzo, M.R.; Melato, M.; Zabucchi, G. The crocidolite fibers interaction with human mesothelial cells as investigated by combining electron microscopy, atomic force and scanning near-field optical microscopy. J. Microsc. 2013, 249, $173-183$. [CrossRef] [PubMed]

32. Bernareggi, A.; Ren, E.; Borelli, V.; Vita, F.; Constanti, A.; Zabucchi, G. Xenopus laevis Oocytes as a Model System for Studying the Interaction Between Asbestos Fibers and Cell Membranes. Toxicol. Sci. 2015, 45, 263-272. [CrossRef] [PubMed]

33. Miles, S.E.; Sandrini, A.; Johnson, A.R.; Yates, D.H. Clinical consequences of asbestos-related diffuse pleural thickening: A review. J. Occup. Med. Toxicol. 2008, 3, 20. [CrossRef] [PubMed]

34. Aust, A.E.; Cook, P.M.; Dodson, R.F. Morphological and chemical mechanisms of elongated mineral particle toxicities. J. Toxicol. Environ. Health B Crit. Rev. 2011, 14, 40-75. [CrossRef] [PubMed]

35. Liu, G.; Cheresh, P.; Kamp, D.W. Molecular basis of asbestos-induced lung disease. Annu. Rev. Pathol. 2013, 24, 161-187. [CrossRef] [PubMed] 
36. Davis, J.M. Further observations on the ultrastructure and chemistry of the formation of asbestos bodies. Exp. Mol. Pathol. 1970, 13, 346-358. [CrossRef]

37. Suzuki, Y. Interaction of asbestos with alveolar cells. Environ. Health Perspect. 1974, 9, 241-252. [CrossRef] [PubMed]

38. Wright, A.; Donaldson, K.; Davis, J.M.G. Cytotoxic Effect of Asbestos on Macrophages in Different Activation States. Environ. Health Perspect. 1983, 5, 147-152. [CrossRef]

39. Roney, P.L.; Holian, A. Possible mechanism of chrysotile asbestos-stimulated superoxide anion production in guinea pig alveolar macrophages. Toxicol. Appl. Pharmacol. 1989, 100, 132-144. [CrossRef]

40. Koerten, H.K.; de Bruijn, J.D.; Daems, W.T. The formation of asbestos bodies by mouse peritoneal macrophages. An in vitro study. Am. J. Pathol. 1990, 137, 121-134. [PubMed]

41. Perkins, R.C.; Scheule, R.K.; Holian, A. In vitro bioactivity of asbestos for the human alveolar macrophage and its modification by IgG. Am. J. Respir. Cell Mol. Biol. 1991, 4, 532-537. [CrossRef] [PubMed]

42. Ando, T.G.T.; Verma, K.; Kagan, E. Asbestos fibers and interferon-gamma up-regulate nitric oxide production in rat alveolar macrophages. Am. J. Respir. Cell Mol. Biol. 1994, 11, 707-715.

43. Hamilton, R.F.; Iyer, L.L.; Holian, A. Asbestos induces apoptosis in human alveolar macrophages. Am. J. Physiol. 1996, 271, L813-L819. [CrossRef] [PubMed]

44. Holian, A.; Uthman, M.O.; Goltsova, T.; Brown, S.D.; Hamilton, R.F., Jr. Asbestos and silica-induced changes in human alveolar macrophage phenotype. Environ. Health Perspect. 1997, 105, 1139-1142. [CrossRef] [PubMed]

45. Afaq, F.; Abidi, P.; Matin, R.; Rahman, Q. Activation of alveolar macrophages and peripheral red blood cells in rats exposed to fibers/particles. Toxicol. Lett. 1998, 99, 175-182. [CrossRef]

46. Flaherty, D.M.; Monick, M.M.; Carter, A.B.; Peterson, M.W.; Hunninghake, G.W. Oxidant-mediated increases in redox factor-1 nuclear protein and activator protein-1 DNA binding in asbestos-treated macrophages. J. Immunol. 2002, 168, 5675-5681. [CrossRef] [PubMed]

47. Blake, D.J.; Bolin, C.M.; Cox, D.P.; Cardozo-Pelaez, F.; Pfau, J.C. Internalization of Libby amphibole asbestos and 80 induction of oxidative stress in murine macrophages. Toxicol. Sci. 2007, 99, 277-288. [CrossRef] [PubMed]

48. Rom, W.N. Role of oxidants in interstitial lung diseases: Pneumoconioses, constrictive bronchiolitis, and chronic tropical pulmonary eosinophilia. Mediat. Inflamm. 2011, 2011, 407657. [CrossRef] [PubMed]

49. Kamp, D.W.; Liu, G.; Cheresh, P.; Kim, S.J.; Mueller, A.; Lam, A.P.; Trejo, H.; Williams, D.; Tulasiram, S.; Baker, M.; et al. Asbestos-induced alveolar epithelial cell apoptosis. The role of endoplasmic reticulum stress response. Am. J. Respir. Cell Mol. Biol. 2013, 49, 892-901. [CrossRef] [PubMed]

50. Ryan, A.J.; Larson-Casey, J.L.; He, C.; Murthy, S.; Carter, A.B. Asbestos-induced disruption of calcium homeostasis induces endoplasmic reticulum stress in macrophages. J. Biol. Chem. 2014, 289, 33391-33403. [CrossRef] [PubMed]

51. Yazdi, A.S.; Guarda, G.; Riteau, N.; Drexler, S.K.; Tardivel, A.; Couillin, I.; Tschopp, J. Nanoparticles activate the NLR pyrin domain containing 3 (Nlrp3) inflammasome and cause pulmonaryinflammation through release of IL-1 $\alpha$ and IL-1ß. Proc. Natl. Acad. Sci. USA 2010, 107, 19449-19454. [CrossRef] [PubMed]

52. Dostert, C.; Pétrilli, V.; Van Bruggen, R.; Steele, C.; Mossman, B.T.; Tschopp, J. Innate immune activation through Nalp3 inflammasome sensing of asbestos and silica. Science 2008, 320, 674-677. [CrossRef] [PubMed]

53. Rydman, E.M.; Ilves, M.; Vanhala, E.; Vippola, M.; Lehto, M.; Kinaret, P.A.; Pylkkänen, L.; Happo, M.; Hirvonen, M.R.; Greco, D.; et al. A single aspiration of rod-like carbon nanotubes induces asbestos-like pulmonary inflammation mediated in part by the IL-1R. Toxicol. Sci. 2015, 147, 140-155. [CrossRef] [PubMed]

54. Maki, Y.; Nishimura, Y.; Toyooka, S.; Soh, J.; Tsukuda, K.; Shien, K.; Furukawa, M.; Muraoka, T.; Ueno, T.; Tanaka, N.; et al. The proliferative effects of asbestos-exposed peripheral blood mononuclear cells on mesothelial cells. Oncol. Lett. 2016, 11, 3308-3316. [CrossRef] [PubMed]

55. Eagan, T.M.L.; Gulsvik, A.; Eide, G.E.; Bakke, P.S. Occupational Airborne Exposure and the Incidence of Respiratory Symptoms and Asthma. Am. J. Respir. Crit. Care Med. 2002, 166, 933-938. [CrossRef] [PubMed]

56. Abraham, S.N.; Thankavel, K.; Malaviya, R. Mast cells as modulators of host defense in the lung. Front. Biosci. 1997, 15, 78-87. [CrossRef]

57. Crivellato, E.; Ribatti, D. The mast cell: An evolutionary perspective. Biol. Rev. Camb. Philos. Soc. 2010, 85, 347-360. [CrossRef] [PubMed] 
58. Trevisan, E.; Vita, F.; Medic, N.; Soranzo, M.R.; Zabucchi, G.; Borelli, V. Mast cells kill Candida albicans in the extracellular environment but spare ingested fungi from death. Inflammation 2014, 37, 2174-2189. [CrossRef] [PubMed]

59. Zabucchi, G.; Trevisan, E.; Vita, F.; Soranzo, M.R.; Borelli, V. NOD1 and NOD2 Interact with the Phagosome Cargo in Mast Cells: A Detailed Morphological Evidence. Inflammation 2015, 38, 1113-1125. [CrossRef] [PubMed]

60. Puxeddu, I.; Piliponsky, A.M.; Bachelet, I.; Levi-Schaffer, F. Mast cells in allergy and beyond. Int. J. Biochem. Cell Biol. 2003, 35, 1601-1607. [CrossRef]

61. Brown, E.J. Integrins, mast cells, and innate immunity. Blood 2004, 103, 1980-1981. [CrossRef]

62. Frossi, B.; De Carli, M.; Pucillo, C. The mast cell: An antenna of the microenvironment that directs the immune response. J. Leukoc. Biol. 2004, 75, 579-585. [CrossRef] [PubMed]

63. Metz, M.; Grimbaldeston, M.A.; Nakae, S.; Piliponsky, A.M.; Tsai, M.; Galli, S.J. Mast cells in the promotion and limitation of chronic inflammation. Immunol. Rev. 2007, 217, 304-328. [CrossRef] [PubMed]

64. Hofmann, A.M.; Abraham, S.N. New roles for MC in modulating allergic reaction and immunity against phatogens. Curr. Opin. Immunol. 2009, 21, 679-686. [CrossRef] [PubMed]

65. Fox, B.; Bull, T.B.; Guz, A. Mast cells in the human alveolar wall: An electronmicroscopic study. J. Clin. Pathol. 1981, 34, 1333-1342. [CrossRef] [PubMed]

66. Choe, N.; Tanaka, S.; Xia, W.; Hemenway, D.R.; Roggli, V.L.; Kagan, E. Pleural macrophage recruitment and activation in asbestos-induced pleural injury. Environ. Health Perspect. 1997, 105, 1257-1260. [CrossRef] [PubMed]

67. Andersson, C.K.; Mori, M.; Bjermer, L.; Löfdahl, C.G.; Erjefält, J.S. Novel site-specific mast cell subpopulations in the human lung. Thorax 2009, 64, 297-305. [CrossRef] [PubMed]

68. Edwards, R.E.; Wagner, M.M.; Moncrieff, C.B. Cell population and histochemistry of asbestos related lesions of rat pleural cavity after injection of various inorganic dusts. Br. J. Ind. Med. 1984, 4, 506-513. [CrossRef]

69. Wagner, M.M.; Edwards, R.E.; Moncrieff, C.B.; Wagner, J.C. Mast cells and inhalation of asbestos in rats. Thorax 1984, 39, 539-544. [CrossRef] [PubMed]

70. Keith, I.; Day, R.; Lemaire, S.; Lemaire, I. Asbestos-induced fibrosis in rats: Increase in lung mast cells and autacoid contents. Exp. Lung Res. 1987, 13, 311-327. [CrossRef] [PubMed]

71. Chen, H.; Xu, Y.; Yang, G.; Zhang, Q.; Huang, X.; Yu, L.; Dong, X. Mast cell chymase promotes hypertrophic scar fibroblast proliferation and collagen synthesis by activating TGF- $\beta 1 /$ Smads signaling pathway. Exp. Ther. Med. 2017, 14, 4438-4442. [CrossRef] [PubMed]

72. Smith, M.J.; Brown, J.M.; Zamboni, W.C.; Walker, N.J. From immunotoxicity to nanotherapy: The effects of nanomaterials on the immune system. Toxicol. Sci. 2014, 138, 249-255. [CrossRef] [PubMed]

73. Xu, J.; Alexander, D.B.; Futakuchi, M.; Numano, T.; Fukamachi, K.; Suzui, M.; Omori, T.; Kanno, J.; Hirose, A.; Tsuda, H. Size- and shape-dependent pleural translocation, deposition, fibrogenesis, and mesothelial proliferation by multiwalled carbon nanotubes. Cancer Sci. 2014, 105, 763-769. [CrossRef] [PubMed]

74. Rydman, E.M.; Ilves, M.; Koivisto, A.J.; Kinaret, P.A.S.; Fortino, V.; Savinko, T.S.; Lehto, M.T.; Pulkkinen, V.; Vippola, M.; Hämeri, K.J.; et al. Inhalation of rod-like carbon nanotubes causes unconventional allergic airway. Part. Fiber Toxicol. 2014, 11, 48. [CrossRef] [PubMed]

75. Aldossari, A.A.; Shannahan, J.H.; Podila, R.; Brown, J.M. Influence of physicochemical properties of silver nanoparticles on mast cell activation and degranulation. Toxicology 2015, 29, 195-203. [CrossRef] [PubMed]

76. Chen, E.Y.; Garnica, M.; Wang, Y.C.; Mintz, A.J.; Chen, C.S.; Chin, W.C. A mixture of anatase and rutile $\mathrm{TiO}_{2}$ nanoparticles induces histamine secretion in mast cells. Part. Fiber Toxicol. 2012, 9, 2. [CrossRef] [PubMed]

77. Governa, M.; Camilucci, L.; Amati, M.; Visonà, I.; Valentino, M.; Botta, G.C.; Campopiano, A.; Fanizza, C. Wollastonite fibers in vitro generate reactive oxygen species able to lyse erythrocytes and activate the complement alternate pathway. Toxicol. Sci. 1998, 44, 32-38. [CrossRef] [PubMed]

78. Kohyama, N.; Shinohara, Y.; Suzuki, Y. Mineral phases and some reexamined characteristics of the International Union against Cancer standard asbestos samples. Am. J. Ind. Med. 1996, 30, 515-528. [CrossRef]

79. Kusiorowski, R.; Zaremba, T.; Gerle, A.; Piotrowski, J.; Simka, W.; Adamek, J. Study on the thermal decomposition of crocidolite asbestos. J. Therm. Anal. Calorim. 2015, 120, 1585-1595. [CrossRef]

80. Sehati, S.; Entezari, M.H. Sono-intercalation of CdS nanoparticles into the layers of titanate facilitates the sunlight degradation of Congo red. J. Colloid. Interface Sci. 2016, 462, 130-139. [CrossRef] [PubMed] 
81. Medic, N.; Vita, F.; Abbate, R.; Soranzo, M.R.; Pacor, S.; Fabbretti, E.; Borelli, V.; Zabucchi, G. Mast cell activation by myelin through scavenger receptor. J. Neuroimmunol. 2008, 200, 27-40. [CrossRef] [PubMed]

82. Shore, P.; Burkhalter, A.; Cohn, V., Jr. A method for the fluorometric assay of histamine in tissues. J. Pharmacol. Exp. Ther. 1959, 127, 182-186. [PubMed]

83. Lindstedt, K.A.; Kovanen, P.T. Isolation of mast cell granules. Curr. Protoc. Cell Biol. 2006, 3, 16. [PubMed]

84. Zabucchi, G.; Menegazzi, R.; Soranzo, M.R.; Patriarca, P. Uptake of human eosinophil peroxidase by human neutrophils. Am. J. Pathol. 1986, 124, 510-518. [PubMed]

85. Menegazzi, R.; Zabucchi, G.; Knowles, A.; Cramer, R.; Patriarca, P. A new, one-step assay on whole cell suspensions.for peroxidase secretion by human neutrophils and eosinophils. J. Leukoc. Biol. 1992, 52, 619-624. [PubMed]

86. Brody, A.R.; George, G.; Hill, L.H. Interactions of chrysotile and crocidolite asbestos with red blood cell membranes. Chrysotile binds to sialic acid. Lab. Investig. 1983, 49, 468-475.

87. Brody, A.R.; Hill, L.H. Interactions of chrysotile asbestos with erythrocyte membranes. Environ. Health Perspect. 1983, 51, 85-89. [CrossRef] [PubMed]

88. Iguchi, H.; Kojo, S. Possible generation of hydrogenperoxide and lipid peroxidation of erythrocyte membrane by asbestos: Cytotoxic mechanism of asbestos. Biochem. Int. 1989, 8, 981-990.

89. Gendek, E.G.; Brody, A.R. Changes in lipid ordering of model phospholipid membranes treated with chrysotile and crocidolite asbestos. Environ. Res. 1990, 53, 152-167. [CrossRef]

90. Elferink, J.G.; Kelters, I. Chrysotile asbestos-induced membrane damage in human erythrocytes. Res. Commun. Chem. Pathol. Pharmacol. 1991, 73, 355-365. [PubMed]

91. Johnson, N.F.; Davies, R. Effect of asbestos on the P388D1 macrophage-like cell line: Preliminary ultrastructural observations. Environ. Health Perspect. 1983, 51, 109-117. [CrossRef] [PubMed]

92. Palomaki, J.; Valimaki, E.; Sund, J.; Vippola, M.; Clausen, P.A.; Jensen, K.A.; Savolainen, K.; Matikainen, S.; Alenius, H. Long, needle-like carbon nanotubes and asbestos activate the Nlrp3 inflammasome through a similar mechanism. ACS Nano 2011, 5, 6861-6870. [CrossRef] [PubMed]

93. Rajotte, D.; Stearns, C.D.; Alisa, K.K. Isolation of Mast Cell Secretory Lysosomes Using Flow Cytometry. Cytom. Part A 2003, 55, 94-101. [CrossRef] [PubMed]

94. Lindstedt, K.A.; Kokkonen, J.O.; Kovanen, P.T. Soluble heparin proteoglycans released from stimulated mast cells induce uptake of low density lipoproteins by macrophages via scavenger receptor-mediated phagocytosis. J. Lipid Res. 1992, 33, 65-75. [PubMed]

95. Wu, L.; Wu, S.; Xu, Z.; Qiu, Y.; Li, S.; Xu, H. Modified nanoporous titanium dioxide as a novel carrier for enzyme immobilization. Biosens. Bioelectron. 2016, 80, 59-66. [CrossRef] [PubMed]

96. Lazarus, G.S. Mastocytosis: New understandings in cutaneous pathophysiology. J. Dermatol. 1996, 23, 769-772. [CrossRef] [PubMed]

97. Lefrançais, E.; Duval, A.; Mirey, E.; Roga, S.; Espinosa, E.; Cayrol, C.; Girard, J.P. Central domain of IL-33 is cleaved by mast cell proteases for potent activation of group-2 innate lymphoid cells. Proc. Natl. Acad. Sci. USA 2014, 28, 15502-15507. [CrossRef] [PubMed]

98. Waern, I.; Lundequist, A.; Pejler, G.; Wernersson, S. Mast cell chymase modulates IL-33 levels and controls allergic sensitization in dust-mite induced airway inflammation. Mucosal Immunol. 2013, 6, 911-920. [CrossRef] [PubMed]

99. Dodson, R.F.; Williams, M.G., Jr.; Corn, C.J.; Brollo, A.; Bianchi, C. Asbestos content of lung tissue, lymph nodes, and pleural plaques from former shipyard workers. Am. Rev. Respir. Dis. 1990, 142, 843-847. [CrossRef] [PubMed]

100. Abel, J.; Goldmann, O.; Ziegler, C.; Höltje, C.; Smeltzer, M.S.; Cheung, A.L.; Bruhn, D.; Rohde, M.; Medina, E. Staphylococcus aureus evades the extracellular antimicrobial activity of mast cells by promoting its own uptake. J. Innate Immun. 2011, 3, 495-507. [CrossRef] [PubMed]

(C) 2018 by the authors. Licensee MDPI, Basel, Switzerland. This article is an open access article distributed under the terms and conditions of the Creative Commons Attribution (CC BY) license (http://creativecommons.org/licenses/by/4.0/). 